\title{
Assessment of atmospheric processes driving ozone variations in the subtropical North Atlantic free troposphere
}

\author{
E. Cuevas ${ }^{1}$, Y. González ${ }^{1}$, S. Rodríguez ${ }^{1}$, J. C. Guerra ${ }^{2}$, A. J. Gómez-Peláez ${ }^{1}$, S. Alonso-Pérez ${ }^{1,3}$, J. Bustos ${ }^{1}$, and \\ C. Milford ${ }^{4,1}$ \\ ${ }^{1}$ Izaña Atmospheric Research Centre (IARC), Agencia Estatal de Meteorología (AEMET), Izaña, Spain \\ ${ }^{2}$ La Laguna University, Hydrometeorology Research Group (GRIHM), (ULL), La Laguna, Spain \\ ${ }^{3}$ Institute of Environmental Assessment and Water Research (CSIC), Barcelona, Spain \\ ${ }^{4}$ University of Huelva, Joint Research Unit to CSIC (UHU), Huelva, Spain \\ Correspondence to: E. Cuevas (ecuevasa@ aemet.es)
}

Received: 1 July 2012 - Published in Atmos. Chem. Phys. Discuss.: 30 October 2012

Revised: 23 January 2013 - Accepted: 28 January 2013 - Published: 20 February 2013

\begin{abstract}
An analysis of the 22-yr ozone $\left(\mathrm{O}_{3}\right)$ series (19882009) at the subtropical high mountain Izaña station (IZO; $2373 \mathrm{~m}$ a.s.1.), representative of free troposphere (FT) conditions, is presented. Diurnal and seasonal $\mathrm{O}_{3}$ variations as well as the $\mathrm{O}_{3}$ trend $\left(0.19 \pm 0.05 \% \mathrm{yr}^{-1}\right.$ or $\left.0.09 \mathrm{ppbv} \mathrm{yr}^{-1}\right)$, are assessed. A climatology of $\mathrm{O}_{3}$ transport pathways using backward trajectories shows that higher $\mathrm{O}_{3}$ values are associated with air masses travelling above $4 \mathrm{~km}$ altitude from North America and North Atlantic Ocean, while low $\mathrm{O}_{3}$ is transported from the Saharan continental boundary layer (CBL). $\mathrm{O}_{3}$ data have been compared with $\mathrm{PM}_{10},{ }^{210} \mathrm{~Pb},{ }^{7} \mathrm{Be}$, potential vorticity $(\mathrm{PV})$ and carbon monoxide $(\mathrm{CO})$. A clear negative logarithmic relationship was observed between $\mathrm{PM}_{10}$ and surface $\mathrm{O}_{3}$ for all seasons. A similar relationship was found between $\mathrm{O}_{3}$ and ${ }^{210} \mathrm{~Pb}$. The highest daily $\mathrm{O}_{3}$ values (90th percentile) are observed in spring and in the first half of summer time. A positive correlation between $\mathrm{O}_{3}$ and $\mathrm{PV}$, and between $\mathrm{O}_{3}$ and ${ }^{7} \mathrm{Be}$ is found throughout the year, indicating that relatively high surface $\mathrm{O}_{3}$ values at IZO originate from the middle and upper troposphere. We find a good correlation between $\mathrm{O}_{3}$ and $\mathrm{CO}$ in winter, supporting the hypothesis of long-range transport of photochemically generated $\mathrm{O}_{3}$ from North America. Aged air masses, in combination with sporadic inputs from the upper troposphere, are observed in spring, summer and autumn. In summer time high $\mathrm{O}_{3}$ values seem to be the result of stratosphere-to-troposphere (STT) exchange processes in regions neighbouring the Canary Islands. Since 1995-1996, the North Atlantic Oscillation has changed from a predominantly high positive phase to al-
\end{abstract}

ternating between negative, neutral or positive phases. This change results in an increased flow of the westerlies in the mid-latitude and subtropical North Atlantic, thus favouring the transport of $\mathrm{O}_{3}$ and its precursors from North America, and a higher frequency of storms over North Atlantic, with a likely higher incidence of STT processes in mid-latitudes. These processes lead to an increase of tropospheric $\mathrm{O}_{3}$ in the subtropical North Atlantic region after 1996 that has been reflected in surface $\mathrm{O}_{3}$ records at IZO.

\section{Introduction}

Ozone $\left(\mathrm{O}_{3}\right)$ is an important trace gas in the troposphere (Fishman and Crutzen, 1978). It affects the oxidizing capacity of the troposphere (Levy, 1971; Logan, 1985; Thompson, 1992), it is a phytotoxicant that can affect public health (Tiao et al., 1975), and is an important greenhouse gas (Ramanathan et al., 1985; Mitchel, 1989). A portion of the $\mathrm{O}_{3}$ is downward transported from the stratosphere (Junge, 1962; Danielsen, 1968; Levy et al., 1985), while most of the tropospheric $\mathrm{O}_{3}$ is believed to be produced in the troposphere itself by photochemical reactions involving nitrogen oxides $\left(\mathrm{NO}_{\mathrm{x}}\right)$ and carbon monoxide $(\mathrm{CO})$ (Lelieveld and Dentener, 2000; Jonson et al., 2006). Thus, $\mathrm{O}_{3}$ concentrations may be viewed as the sum of a global/hemispheric background concentration and regionally/locally produced $\mathrm{O}_{3}$ (Jonson et al., 2006). 
Results from Graustein and Turekian (1996) indicate an upper troposphere source for elevated $\mathrm{O}_{3}$ in summer time subtropical free troposphere (FT) of the eastern North Atlantic, and James et al. (2003) found evidence of deep stratospheric intrusions down to the lower FT over the Canaries even in summer. Oltmans et al. (1996) reported evidence of high $\mathrm{O}_{3}$ concentration $(\sim 100 \mathrm{ppb})$ layers in the middle and upper troposphere over the North Atlantic which are invariably associated with transport characteristics that strongly support a stratospheric source for these layers.

However, other authors (e.g. Moody et al., 1996; Creilson et al., 2003; Hegarty et al., 2009) suggest that a substantial amount of photochemically generated tropospheric $\mathrm{O}_{3}$ is transported from continental source regions over the North Atlantic. Some studies have revealed the great impact of this pollution over the air quality of Europe (e.g. Parrish et al., 1993; Li et al., 2002a; Prather et al., 2003). As pointed out by Stohl (2001) and Stohl et al. (2002), the long-range transport of $\mathrm{O}_{3}$ from North America to Europe is more efficient in the middle and upper FT because the westerlies are stronger than in the marine boundary layer (MBL), and also because of a longer $\mathrm{O}_{3}$ lifetime. Val Martin et al. (2008) suggest that a substantial amount of additional $\mathrm{O}_{3}$ formation occurs in the anthropogenic plumes during transport to the central North Atlantic lower FT.

Assessment of long-term trends in tropospheric $\mathrm{O}_{3}$ is difficult due to the scarcity of representative observing sites with long records (Solomon et al., 2007). In addition, the longterm tropospheric $\mathrm{O}_{3}$ trends vary both in terms of sign and magnitude and in the possible causes of the change (Oltmans et al., 2006). Some $\mathrm{O}_{3}$ trends have been attributed to changes in $\mathrm{O}_{3}$ precursor emissions (Scheel, 1983). However, further studies reveal that $\mathrm{O}_{3}$ trends cannot be fully explained based on its precursors alone. For example, Staehelin and Poberaj (2008) argue that further increase in background $\mathrm{O}_{3}$ over Europe and North America since the early 1990s cannot be solely explained by regional $\mathrm{O}_{3}$ precursor changes because anthropogenic $\mathrm{O}_{3}$ precursor emissions were drastically reduced in the industrialized countries as a consequence of air quality legislation. Gilge et al. (2010) also state the apparent contradiction between the rather constant $\mathrm{O}_{3}$ concentrations observed at ground stations during the end of the 1990s to 2007 and the substantial reductions in anthropogenic emissions. The surface $\mathrm{O}_{3}$ positive trend found at elevated European sites was explained by Ordóñez et al. (2007) in terms of an increased contribution of stratospheric $\mathrm{O}_{3}$ in the 90 s. Conversely, Tarasova et al. (2003) found negative trends in a high mountain in Russia, and Vingarzan (2004) and Tarasova et al. (2009) reported a slower rate of tropospheric $\mathrm{O}_{3}$ increase or in some cases lack of an increase over the past decade. Logan et al. (2012) found a slow decrease in summer surface ozone in alpine stations and in the free troposphere over Europe, with an average trend of $-0.15 \mathrm{ppbyr}^{-1}$ since 1998. Spatial and temporal evolution of atmospheric processes driving $\mathrm{O}_{3}$ concentrations affect stations located in different regions of the world in different ways, as it has been recently reported by Oltmans et al. (2013). In this regard Jonson et al. (2006) address the question if the observed $\mathrm{O}_{3}$ trends can be understood.

Model simulations suggest that the increase of background tropospheric $\mathrm{O}_{3}$ observed in mountain tops can be only partially explained by changes in emissions of precursors over continents, and may be affected by changes in the circulation of the troposphere (Jonson et al., 2006). For example, Appenzeller et al. (2000) found a good correlation between the North Atlantic Oscillation (NAO) index and column tropospheric $\mathrm{O}_{3}$ over the eastern North Atlantic, and Eckhardt et al. (2003) demonstrated how the NAO controls the air pollution transport to the Arctic. Duncan and Bey (2004) explained that the $\mathrm{CO}$ burden from Europe tended to be higher over the North Atlantic and lower over the Arctic when the NAO was in the negative phase. So, reductions in $\mathrm{O}_{3}$ caused by reductions in precursors may be masked by periodical changes in atmospheric circulation. As noted by Jonson et al. (2006), the changes suffered by the stratospheric $\mathrm{O}_{3}$ in the last decades could alter the circulation patterns, which would affect, in turn, the exchange between the stratosphere and troposphere.

Most of the studies address the origin of tropospheric ozone from only one of the most common approaches: photochemistry or atmospheric dynamics, which is a limited and partial view of the driving forces. Therefore, we propose, firstly, a detailed analysis of a long-term ( $22 \mathrm{yr}$ ) surface $\mathrm{O}_{3}$ time series (1988-2009) at the Izaña high mountain station (hereafter IZO), which is representative of background conditions of the lower troposphere in the subtropical North Atlantic region, where there is very little information available. Secondly, we present an extensive and multidisciplinary review of the $\mathrm{O}_{3}$ transport processes into the FT of the North Atlantic subtropical region, incorporating other components such as particulate matter, $\mathrm{CO},{ }^{7} \mathrm{Be},{ }^{210} \mathrm{~Pb}$, and additional information from backward trajectories, potential vorticity $(\mathrm{PV})$, and the NAO index.

The surface $\mathrm{O}_{3}$ measurement programme of IZO is run with an independent quality assurance system, within the World Meteorological Organization (WMO) Global Atmospheric Watch (GAW) Programme, which precludes data biases and prevents wrong interpretations in trends analysis. Our paper is structured as follows: data and methods are described in Sect. 2. In Sect. 3 a surface $\mathrm{O}_{3}$ climatology and transport pathways characterization is presented, and a discussion about surface $\mathrm{O}_{3}$ observations, their relationships with other atmospheric components $\left(\mathrm{PM}_{10},{ }^{210} \mathrm{~Pb}, \mathrm{PV},{ }^{7} \mathrm{Be}\right.$, and $\mathrm{CO}$ ), and their connections with synoptic-scale dynamical processes driven by the NAO is given. In Sect. 4 a summary and main conclusions are provided. 


\section{Data and methods}

\subsection{Measurement site}

The Izaña GAW Observatory is located at $28.3^{\circ} \mathrm{N}, 16.5^{\circ} \mathrm{W}$ at an altitude of $2373 \mathrm{~m}$ a.s.l. (annual mean pressure of $\sim 770 \mathrm{hPa}$ ) on Tenerife Island, (Canary Islands, Spain) on top of a mountain platform on a dorsal ridge which crosses the island from SW to NE. A belt of endemic pine forest $(P i$ nus Canariensis CHr, Sm. Ex DC) grows between 600 and $2000 \mathrm{~m}$ a.s.l., whereas at higher levels there is only a sparse cover of local species of broom (Spartocytisus supranubius) growing on lava terrain. Except for a few scattered residences, Tenerife is uninhabited above the $1000 \mathrm{~m}$ level. The horizontal distances from IZO to the north-west and to the south-east coasts (the direction of the prevailing winds) are less than $15 \mathrm{~km}$. The nearest distance to the European continent is $1300 \mathrm{~km}$ and about $350 \mathrm{~km}$ to Africa.

\subsection{In situ surface $\mathrm{O}_{3}$ instrumentation}

The surface $\mathrm{O}_{3}$ monitoring programme at IZO started in May 1987 using a UV absorption technique. The analysers used in different periods from this time up to the present, as well as the reference instruments and the quality assurance programmes are specified in Table 1. The terminology used in Table 1 is the following:

- Basic instrument: analyser from which the final data result.

- Backup instrument: instrument that is monitoring in parallel to the basic analyser.

- Reference instrument: analyser for independent comparisons and calibrations (not used for ambient air measurements).

$\mathrm{O}_{3}$ has been measured continuously recording 10-min averages with the corresponding standard deviation from May 1987 to July 1996. After this date, and up to now, 1min average $\mathrm{O}_{3}$ values with corresponding standard deviations are recorded for both the basic and the backup instruments. Zero-checks with an activated-carbon absorber were performed on a daily basis to detect instrumental offset drifts. Surface $\mathrm{O}_{3}$ data at IZO have been also calibrated against references that are traceable to NIST (US National Institute for Standards and Technology) reference $\mathrm{O}_{3}$ photometer (Gaithersburg, Maryland, USA). The Izaña surface $\mathrm{O}_{3}$ programme has been audited by the World Calibration Centre for Surface Ozone, Carbon Monoxide and Methane (WCC-Ozone-CO-CH4-EMPA) in 1996, 1998, 2000, 2004 and 2009. EMPA's audit reports are available at http://www. empa.ch/gaw/audits/IZO_yyyy.pdf, where yyyy is the year. The audits were performed according to the "Standard Operating Procedure (SOP) for performance auditing $\mathrm{O}_{3}$ analysers at global and regional WMO-GAW sites", WMOGAW Report No. 97. All audited field instruments (basic and backup instruments) fulfilled the assessment criteria as "good" over the tested range up to 100 ppbv.

\subsection{Backward trajectories, $\mathrm{O}_{3}$ MCAR plots, residence times, and BTMH plots}

Five-day HYSPLIT (Hybrid Single-Particle Lagrangian Integrated Trajectory) version 4.0 dispersion model backward trajectories (Draxler and Rolph, 2003; Rolph, 1983) with a time resolution of $1 \mathrm{~h}$ were calculated using the FNL (Final Analysis Data) meteorological dataset (from May 1987 to December 2004) and the GDAS (Global Data Assimilation System) meteorological dataset (from January 2004 to December 2009), both from the National Centres for Environmental Prediction. The vertical component of the backward trajectories was computed using the vertical model velocity. The end point was set at Tenerife $\left(28.3^{\circ} \mathrm{N}, 16.5^{\circ} \mathrm{W}\right)$ at $2400 \mathrm{~m}$ a.s.l. (IZO height) for each day of the study period (1 January 1988-31 December 2009) at 00:00 UTC.

The transport paths of the air masses reaching Tenerife (00:00 UTC) have been characterized using the permanence indices for the predefined source geographic sectors described in Alonso-Pérez et al. (2007) and summarized in Table 2. Permanence indexes were calculated as the fraction of time that an air mass trajectory calculated for $120 \mathrm{~h}$ resides in a predefined particular geographic sector and also in a predefined altitude range. We consider "low" an altitude range between surface level and $1.5 \mathrm{~km}$, "medium" an altitude range between 1.5 and $3 \mathrm{~km}$, and "high" $>3 \mathrm{~km}$ (normally with a top height at $6 \mathrm{~km}$ ). Permanence indexes were obtained using 5-day HYSPLIT backward trajectories.

Source-receptor relationships of atmospheric composition can be investigated with backward trajectory techniques, tracing forward from a defined geographical origin to arrive at measurement sites where the composition may have altered during transport (Fleming et al., 2012). One of these techniques is the so-called "mean concentrations at receptor" (MCAR). For each pixel of our geographical domain, we select the backward trajectories which arrive at IZO and pass over that pixel. The daily mean $\mathrm{O}_{3}$ concentrations measured at Izaña on the corresponding trajectory arrival days are averaged, and this average is plotted on that pixel. MCAR plots allowed the identification of pathway regions with high and low $\mathrm{O}_{3}$. The methodology has been described by Rodríguez et al. (2011). Monthly MCAR plots of surface $\mathrm{O}_{3}$ were determined using daily 5-day backward trajectories calculated at 00:00 UTC and daily (nocturnal) surface $\mathrm{O}_{3}$ data at IZO for the period 1988-2009.

The identification of the transport corridors and source regions of $\mathrm{O}_{3}$ was complemented by using the residence time analysis technique (Poirot and Wishinski, 1986). For this issue, the geophysical region covered by the trajectories was divided into 408 grid cells of $5^{\circ} \times 5^{\circ}$ (latitude/longitude). The problem with this method is that all of the backward trajectories begin at the receptor site, and thus the residence time 
Table 1. Description of $\mathrm{O}_{3}$ analysers, associated quality assurance, and data acquisition system used during the period 1988-2009. $\mathrm{Ri}=$ Reference instrument; $\mathrm{Bi}=$ Basic instrument; $\mathrm{Bp}=$ Backup instrument $\mathrm{MPC}=$ Multipoint calibration.

\begin{tabular}{|c|c|c|c|c|}
\hline Period & Instrument & $\begin{array}{l}\text { Calibration system/ } \\
\text { Quality Assurance }\end{array}$ & International Reference & Data acquisition \\
\hline May 87-Jul 95 & $\begin{array}{l}\text { Dasibi-1008-AH } \\
\quad \# 4283(\mathrm{Bi})\end{array}$ & $\begin{array}{l}\text { Dasibi-1008-RS } \\
\quad \# 5797(\mathrm{Ri}) \\
\text { MPC/ } 2 \text { months }\end{array}$ & NIST Traceable & $\begin{array}{c}\text { Continuous } \\
\text { Record: } 10 \min \pm \mathrm{SD}\end{array}$ \\
\hline Jul 95-Jul 96 & $\begin{array}{l}\text { Dasibi-1008-RS } \\
\text { \#5797 (Bi) }\end{array}$ & & NIST Traceable & $\begin{array}{c}\text { Continuous } \\
\text { Record: } 10 \mathrm{~min} \pm \mathrm{SD}\end{array}$ \\
\hline Jul 96-Feb 99 & $\begin{array}{c}\text { TEI 49-C } \\
\text { \#55912-305(Bi) } \\
\text { Dasibi-1008-RS } \\
\quad \# 5797(\mathrm{Bp})\end{array}$ & $\begin{array}{c}\text { EMPA Audit (Nov 96) } \\
\text { TEI 49C-PS } \\
\text { \#56085-306 (Ri) (Apr 97) } \\
\text { MPC/ } 3 \text { months } \\
\text { EMPA Audit (Feb 98) }\end{array}$ & NIST-EMPA & $\begin{array}{c}\text { Continuous } \\
\text { Record: } 1 \min \pm \mathrm{SD}\end{array}$ \\
\hline Feb 99-Nov 03 & $\begin{array}{c}\text { TEI 49-C } \\
\# 62900-337(\mathrm{Bi}) \\
\text { Dasibi-1008-RS } \\
\quad \# 5797(\mathrm{Bp})\end{array}$ & $\begin{array}{c}\text { TEI 49C-PS } \\
\text { \#56085-306(Ri) } \\
\text { MPC/ } 3 \text { months } \\
\text { EMPA Audit (Jun 00) }\end{array}$ & NIST-EMPA & $\begin{array}{c}\text { Continuous } \\
\text { Record: } 1 \mathrm{~min} \pm \mathrm{SD}\end{array}$ \\
\hline Nov 03-Now & $\begin{array}{c}\text { TEI 49-C } \\
\# 62900-337(\mathrm{Bi}) \\
\text { TEI 49-C } \\
\# 72491-371(\mathrm{Bp})\end{array}$ & $\begin{array}{c}\text { TEI 49C-PS } \\
\text { \#56085-306(Ri) } \\
\text { EMPA Audit (Nov 04) } \\
\text { EMPA Audit (Nov 09) }\end{array}$ & NIST-EMPA & $\begin{array}{c}\text { Continuous } \\
\text { Record: } 1 \text { min } \pm \mathrm{SD}\end{array}$ \\
\hline
\end{tabular}

Table 2. Geographical sectors used in the backward trajectory classification (function of the continental source regions and oceanic sectors, latitude and longitude ranges).

\begin{tabular}{lll}
\hline Sector & $\begin{array}{l}\text { Latitude } \\
\text { Range }\end{array}$ & $\begin{array}{l}\text { Longitude } \\
\text { Range }\end{array}$ \\
\hline North America & $30-90^{\circ} \mathrm{N}$ & $50-135^{\circ} \mathrm{W}$ \\
North Atlantic & $30-90^{\circ} \mathrm{N}$ & $10.5-70^{\circ} \mathrm{W}$ \\
North Europe & $50-90^{\circ} \mathrm{N}$ & $10.5^{\circ} \mathrm{W}-50^{\circ} \mathrm{E}$ \\
South Europe & $36-50^{\circ} \mathrm{N}$ & $10.5^{\circ} \mathrm{W}-50^{\circ} \mathrm{E}$ \\
Sahara & $20-36^{\circ} \mathrm{N}$ & $18^{\circ} \mathrm{W}-50^{\circ} \mathrm{E}$ \\
Sahel & $0-20^{\circ} \mathrm{N}$ & $18^{\circ} \mathrm{W}-50^{\circ} \mathrm{E}$ \\
Subtropical North Atlantic & $0-30^{\circ} \mathrm{N}$ & $18-135^{\circ} \mathrm{W}$ \\
Canary Islands & $24.7-31.9^{\circ} \mathrm{N}$ & $12.4-20.6^{\circ} \mathrm{W}$ \\
\hline
\end{tabular}

is maximum in the cells surrounding the sampling location (Hopke et al., 2005). We refer to this effect as "central convergence". We have used a modification proposed by Poirot and Wishinski (1986) to avoid the geometrical "central convergence" effect and highlight the distant $\mathrm{O}_{3}$ sources.

Backward trajectories have been also used to compute backward trajectory mean height (BTMH) plots. In this case, on each pixel $\left(1^{\circ} \times 1^{\circ}\right.$ cell $)$, the mean height at that pixel of the backward trajectories which arrive at IZO and pass over that pixel is plotted.

\subsection{Potential vorticity}

Potential vorticity ( $\mathrm{PV} ; 1 \mathrm{PVU}=10^{-6} \mathrm{~m}^{2} \mathrm{~s}^{-1} \mathrm{Kkg}^{-1}$ ) analysis is a widely used tool to understand the stratosphere-totroposphere (STT) exchange (e.g. Danielsen, 1968) since PV - the product of absolute vorticity and thermodynamic stability - is greater in the stratosphere than in the troposphere (Hoskins et al., 1985). The dynamical tropopause is typically defined with a PVU value ranging from $1 \mathrm{PVU}$ (Shapiro et al., 1987) to 2 PVU (Appenzeller et al., 1996; Parrish et al., 2000). The dynamical tropopause is defined by (WMO) as the 1.6 PVU iso-surface. This value is used by some authors to identify the signature of stratospheric air (e.g. Stohl et al., 2000; Cristofanelli et al., 2006), while other authors consider two threshold values for the dynamical tropopause -2 and 1.5 PVU - for deep stratospheric intrusion analysis, as Akritidis et al. (2010). It is assumed that PV > 1 PVU are typical values of tropospheric regions that have been impacted by stratospheric intrusions. Beekman et al. (1994) made use of the positive correlation of $\mathrm{PV}$ with $\mathrm{O}_{3}$ in separating tropospheric $\mathrm{O}_{3}$ sources on the basis of high and low PV. However, we should note that diabatic heating can reduce the PV values without changing $\mathrm{O}_{3}$. Thus, $\mathrm{PV}$ must be viewed as a bottom indicator of air masses with upper troposphere/lower stratosphere (UTLS) signature.

PV was obtained from ERA-Interim ECMWF (European Centre for Medium-Range Weather Forecasts) reanalysis. 
Daily reanalyses at 00:00, 06:00, 12:00 and 18:00 UTC were retrieved at 300,400,500,600,700,775, 850 and $925 \mathrm{hPa}$ levels from January 1988 to December 2009 in a regular grid with a spatial resolution of $0.5^{\circ}$ latitude/longitude within the geographical domain $20^{\circ} \mathrm{N}-50^{\circ} \mathrm{W} / 70^{\circ} \mathrm{N}-30^{\circ} \mathrm{E}$.

Maximum $\mathrm{PV}\left(\mathrm{PV}_{\max }\right)$ intercepted by daily 5-day backward trajectories for IZO was computed as follows: for each one of the $120 \mathrm{~h}$ of the backward trajectory, the PV is calculated by performing a 3-D nearest-neighbour interpolation with the 8-isobaric PV levels of the ECMWF reanalysis. PV was stored for each 1-h point back of the back trajectory. In this work we have used the $\mathrm{PV}_{\max }$ found along each backward trajectory together with its latitude and longitude.

\section{$2.5 \quad{ }^{7} \mathrm{Be}$ and ${ }^{210} \mathrm{~Pb}$ radiotracers}

The ${ }^{210} \mathrm{~Pb}$ radiotracer (half-life $22 \mathrm{yr}$ ) is the decay daughter of ${ }^{222} \mathrm{Rn}$ (half-life 3.8 days) which is emitted from soils (Turekian et al., 1977). So, ${ }^{210} \mathrm{~Pb}$ is a tracer of air masses with continental boundary layer (CBL) signature (Balkanski et al., 1993). The ${ }^{7} \mathrm{Be}$ radiotracer (half-life 53.3 days) is produced by cosmic ray spallation reactions with nitrogen and oxygen in the stratosphere and upper troposphere (Viezee and Singh, 1980).

The ${ }^{7} \mathrm{Be}$ and ${ }^{210} \mathrm{~Pb}$ radionuclides were measured at IZO on a daily basis within the AEROCE (AEROsol Ocean chemistry Experiment) project (Prospero et al., 1995) in the period of 1989-1991 as tracers for UTLS and CBL air, respectively.

\subsection{Carbon monoxide (CO)}

Carbon monoxide (CO) is a good tracer of anthropogenic pollution because it has a relatively long lifetime in the FT, which permits the study of long-range transport. Daily and hourly night-time $\mathrm{CO}$ averaged concentrations at IZO, corresponding to the period 2008-2011, have been used for the analysis of long-range transport of photochemical $\mathrm{O}_{3}$ from polluted regions. $\mathrm{CO}$ concentrations have been obtained using an automated TEI 48C-TL (Thermo Electron Corporation) NDIR instrument. The NDIR system was calibrated every 3 months using a 10-ppm $\mathrm{CO}$ in $\mathrm{N}_{2}$ standard from Air Liquide. Automatic zero checks and ambient air measurements are alternated in 15-min intervals to account for shortterm drift. A Sofnocat $423 \mathrm{CO}$ scrubber is used for the zero checks. The inlet filter is exchanged every 3 months. Oneminute averages including additional instrument status information are stored. The NDIR system has been audited by the WCC-Ozone-CO-CH4-EMPA in 2009. This audit confirmed the stability and linearity of the instrument, and showed an error of about $10 \%$ when compared to EMPA reference. However, continuous NDIR data have been corrected using discrete NOAA measurements of weekly samples collected in flasks. Consequently, we expect an error lower than $10 \%$. $\mathrm{CO}$ data are used in this work to assess pollution long-range transport by analyzing averaged daily $\mathrm{O}_{3} / \mathrm{CO}$ ratios. Thus, the error associated to $\mathrm{CO}$ measurements is acceptable for our purposes.

\subsection{1 $\mathrm{PM}_{10}$}

Daily nocturnal $\mathrm{PM}_{10}$ (particles less than 10 microns in diameter) concentrations at IZO in the period 2002-2009 have been used for assessing the impact of dust-laden Saharan air masses on $\mathrm{O}_{3}$ records. The $\mathrm{PM}_{10}$ measurement programme was described by Rodríguez et al. (2011).

\subsubsection{North Atlantic Oscillation (NAO) index}

The NAO is one of the major teleconnection patterns of the winter Northern Hemisphere (Wallace and Gutzler, 1981), and represents a measure of the strength of the westerlies across the North Atlantic. Monthly mean values of the NAO index have been obtained from NOAA Climate Prediction Center ftp://ftp.cpc.ncep.noaa.gov/wd52dg/data/indices/ nao_index.tim. Indices are normalized using the 1981-2010 base period monthly means and standard deviations.

\subsubsection{Tropospheric Ozone Residual (TOR)}

Tropospheric Ozone Residual (TOR) data are measurements of tropospheric $\mathrm{O}_{3}$ obtained by subtracting the stratospheric component of $\mathrm{O}_{3}$ (in the stratospheric aerosol and gas experiment) from the total atmospheric column of $\mathrm{O}_{3}$ (by use of the Total Ozone Measurement Spectrometer (TOMS) and Solar Backscattered Ultraviolet (SBUV) instruments).

Data over the North Atlantic, northern Africa and Europe within the geographical domain $10^{\circ} \mathrm{N}-30^{\circ} \mathrm{E} / 50^{\circ} \mathrm{N}-60^{\circ} \mathrm{W}$ have been computed from the database available at the following NASA site: http://asd-www.larc.nasa.gov/TOR/data. $\mathrm{html}$. A description of the technique can be found in Fishman and Balok (1999) and Fishman et al. (2003).

The TOR seasonal average value for each phase of the NAO within the period 1988-2005 was obtained by averaging for each season the TOR monthly mean values of those months in which $\mathrm{NAO}>+0.5$ (positive NAO) or NAO $<$ -0.5 (negative NAO). Thus, to calculate the TOR mean value corresponding to winter of positive NAO phase, seventeen months of ten years were used; for winter of negative NAO phase, three months of three years; for spring of positive NAO phase, twelve months of nine years; and for spring of negative NAO phase, eleven months of nine years. It should be noted that no TOR data are available in 1994, 1995 and 1996, and in much of the years 1993 and 1997.

\section{Results}

\subsection{Surface $\mathrm{O}_{3}$ diurnal cycle}

Large-scale subsidence, associated to the descending branch of the Hadley cell, is an important meteorological feature of 


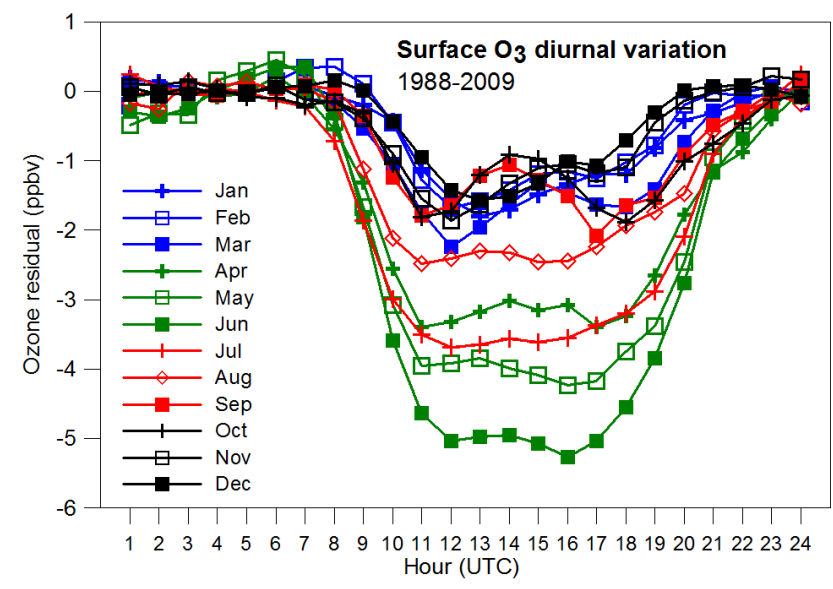

Fig. 1. Mean diurnal variation of surface $\mathrm{O}_{3}$ residuals for each month of the year in the period 1988-2009. The $\mathrm{O}_{3}$ residuals have been calculated on a daily basis as the differences of surface $\mathrm{O}_{3}$ for every hour compared with the night background level.

the subtropical North Atlantic region. The quasi-permanent NNE trade winds flow over a relatively cold ocean surface that inhibits the development of convection in the MBL and enhances subsidence. A temperature inversion layer (TIL) separates two well-differentiated air masses: the MBL and the FT (Font, 1956). The TIL is characterized by a layer of stratocumulus formed by condensation of water vapour onto the available pre-existing particles. The top of the TIL is generally located around $1200 \mathrm{~m}$ a.s.1. in summer, and around $1800 \mathrm{~m}$ a.s.l. in winter. IZO normally lies above the TIL that traps local island pollutant emissions. However, under certain synoptic conditions, normally in winter, the TIL reaches the station level or, simply, the TIL is not observed. The effectiveness of the inversion in separating the MBL from the FT at IZO is reflected in the relative humidity typically $>60 \%$ below the TIL and $\sim 20 \%$ above it. Diurnal variations in the altitudes of the bottom (1200 m during daylight and $900 \mathrm{~m}$ at night) and the top (1700 $\mathrm{m}$ during daylight and $1300 \mathrm{~m}$ at night) of the TIL are observed. The influence of buoyant airflows caused by the heating of the air located just above the terrain of the island is observed at IZO. This upslope effect is reflected in the daily cycle of $\mathrm{CO}_{2}$ concentrations that shows lower values and higher standard deviations during daylight due to uptake by vegetation growing at lower elevations on the slopes (Cuevas et al., 1992). During the night a catabatic air flow regime is well established over the station, favouring the arrival of very clean air masses from higher levels.

The diurnal cycles of $\mathrm{O}_{3}$ (Fig. 1) were obtained from the differences of $\mathrm{O}_{3}$ for every hour compared with the night background level. The reference background level has been computed as follows. Firstly, the averages of the pre- (00:0007:00 h UTC) and post- (21:00-04:00 h UTC) nights were computed. Then, the linear drift in time passing through both averages is used as the reference background level. The use

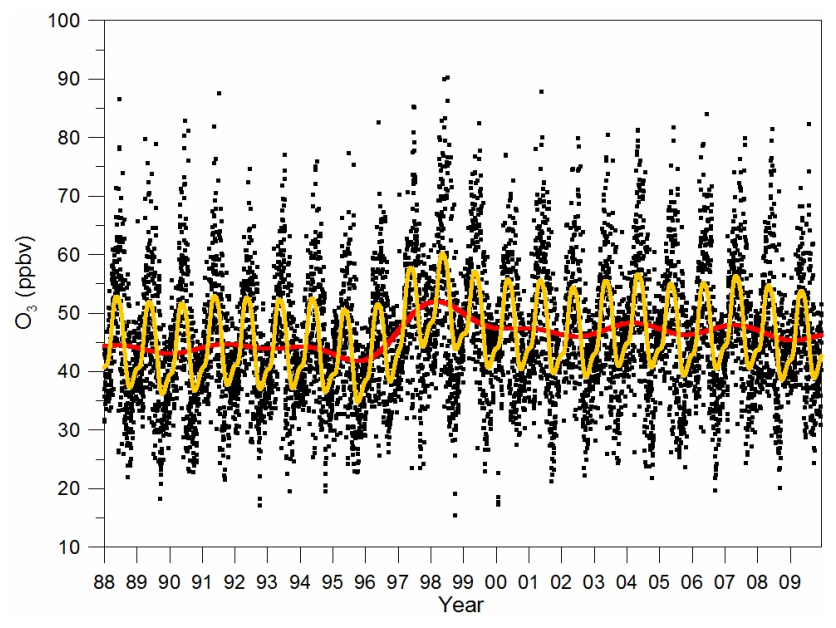

Fig. 2. Surface $\mathrm{O}_{3}$ daily night means (black dots), interannual trend (red line) and interannual trend plus annual cycle at IZO from 1988 to 2009 .

of a linear drift allows for a background trend. Diurnal cycles of surface $\mathrm{O}_{3}$ have been averaged for each month using hourly data for the entire period 1988-2009.

Surface $\mathrm{O}_{3}$ diurnal variations show the lowest values during the afternoon due to an efficient dry deposition on very rough and dark volcanic mountain slopes covered with scattered bushes. This diurnal cycle is the opposite to that recorded in continental regions where a maximum during daylight is observed due to the photochemical production (e.g. Millán et al., 1997). The monthly mean difference between the daily upslope and the nocturnal downslope surface $\mathrm{O}_{3}$ values is within $2 \mathrm{ppbv}$ in winter and autumn. However, in summer and spring day/night differences are normally above $2 \mathrm{ppbv}$, being somewhat greater than $5 \mathrm{ppbv}$ in June, and reaching up to $25 \mathrm{ppbv}$ in some days. The amplitude and width of the diurnal $\mathrm{O}_{3}$ "valley" is basically modulated by two factors: the solar radiation and the consequent heating of the slopes surrounding the observatory, and the strength of the synoptic wind. In winter time the heating of the slopes is minimal, and the strong synoptic winds dilute air masses from lower levels. By contrast, in spring and summer there are the following occurrences: (1) there is a strong warming of the soil (facilitating the mountain breeze); (2) the TIL associated to trade winds is recorded at its lowest level (around $800-1100 \mathrm{~m}$ a.s.1.), so the air flows from lower levels, where $\mathrm{O}_{3}$ concentration is lower, and with a longer path available for dry deposition; and (3) the synoptic winds are usually very weak, resulting in a lower dilution of upslope air. The "ozone valley" in the daytime is a feature also observed in other high mountain stations: Mauna Loa (Oltmans and Levy II, 1994), and Jungfraujoch (Schuepbach et al., 2001). 


\subsection{Annual and seasonal variations of surface $\mathrm{O}_{3}$}

Daily nocturnal (22:00-06:00 UTC) $\mathrm{O}_{3}$ values - representative of subtropical FT conditions - have been analyzed for the entire record (1988-2009) using decomposition in three terms: interannual trend, annual cycle, and residual. A least squares fit of the daily data to the function

$f(t)=\mathrm{a}_{1}+\mathrm{a}_{2} t+\mathrm{a}_{3} t^{2}+\sum_{i=1}^{p}\left[b_{i} \cos \left(w_{i} t\right)+\right.$

$c_{i} \sin \left(w_{i} t\right]+\sum_{j=1}^{4}\left[d_{j} \cos \left(k_{j}\right) t+e_{j} \sin \left(k_{j} t\right)\right]$,

has been performed, where $t$ is the time in days $(t=1$ for 1 January 1988), $a_{1}, a_{2}, a_{3}, b_{i}$ and $c_{i}$ are the parameters of the interannual trend to be determined, $p=7, d_{j}$ and $e_{j}$ are the parameters of the annual cycle (which is assumed constant) to be determined, $w_{i}=2 \pi i / N$ with $N$ equal to the number of days in the period 1988-2009 $(N=8036$, number of valid data $=7790$ ), and $k_{j}=2 \pi j / T$ with $T=365.25$ days. See Gómez-Peláez et al. (2006) for a detailed interpretation of this function. Note that in this work we have added a quadratic term in time, following Gómez-Peláez et al. (2010), in order to allow a non-periodic growth rate.

Figure 2 shows the interannual trend and the interannual trend + annual cycle. The average yearly mean $\mathrm{O}_{3}$ value at IZO for the $22 \mathrm{yr}$ period is $46.1 \mathrm{ppbv}$. The corresponding standard deviation of the mean is $0.12 \mathrm{ppbv}$. The root mean square of the residuals is $8.9 \mathrm{ppbv}$, and the peak-to-peak annual cycle amplitude is $15.4 \mathrm{ppbv}$. The $\mathrm{O}_{3}$ increase observed between 1996 and 1998 is striking. There is a slight positive trend in the annual mean $\left(0.09 \pm 0.02 \mathrm{ppbvyr}^{-1}\right.$ or $0.19 \pm 0.05 \% \mathrm{yr}^{-1}$ ) that is slightly lower than at Mauna Loa $\left(0.37 \pm 0.26 \% \mathrm{yr}^{-1}\right.$, Oltmans and Levy II, 1992). In European alpine stations such as Sonnblick, Jungfraujoch, Hohenpeissenberg and Zugspitze trends are observed in the $0.1-0.4 \% \mathrm{yr}^{-1}$ range (Gilge et al., 2010). Over some Europeans stations (Hohenpeissenberg, Zugspitze and Mace Head) small trends or reductions during summer are observed, while there is an increase during winter (Oltmans et al., 2006). Mace Head, a site that is representative of $\mathrm{O}_{3}$ changes in the air advected from the North Atlantic to Europe in the MBL, has shown a positive trend of $0.16 \pm$ $0.04 \mathrm{ppbyr}^{-1}$ over the entire period 1988-2007, but this positive trend has reduced during recent years (Tripathi et al., 2010). Hence, tropospheric $\mathrm{O}_{3}$ trends over Europe do not show a homogeneous behaviour.

Long-term $\mathrm{O}_{3}$ series should be analyzed by seasons since the processes of transport/production of surface $\mathrm{O}_{3}$ and its precursors can be very different in each season. In Fig. 3 we have plotted the long-term surface $\mathrm{O}_{3}$ P10th, P25th, P50th, P75th and P90th (1988-2009) for winter, spring, summer and autumn. Pnth is the $n$-percentile. In winter a change (increase) in all percentiles is observed in 1997 with a maximum in 1999. A similar behaviour is found in spring, but only in
P50th, P75th and P90th with maximum values in 1998. The lower percentiles do not show significant changes. In summer the increase is smoothed, being only evident in higher percentiles (P75th and P90th). In autumn the change is observable from 1996 in percentiles $\geq$ P50th. Changes in percentile data series observed in the period 1996-1998 will be discussed in Sect. 4.

Figure 4a shows non-detrended monthly means for surface $\mathrm{O}_{3}$ at IZO, Mauna Loa (Oltmans and Levy II, 1994), Zugspitze-Schneefernerhaus (Nienerowski, 2004), Jungfraujoch (Logan et al., 2012), and Sonnblick (Federal Environment Agency Austria). Data from Mauna Loa and the alpine stations have been downloaded from the World Data Centre for Greenhouse Gases (WDCGG; http://ds.data.jma. go.jp/gmd/wdcgg/). IZO shows characteristics intermediate to those recorded at Mauna Loa and the alpine stations. Rodríguez et al. (2004) compared the $\mathrm{O}_{3}$ annual course at IZO with that observed at Mauna Loa, noting that in summer $\mathrm{O}_{3}$ monthly means sharply decrease in the latter, while high $\mathrm{O}_{3}$ events (daily mean values of 60-70 ppbv) are recorded at IZO. However, the typical continental annual cycle, with a broad spring/summer maximum observed in the alpine stations, is not seen at IZO where the annual cycle peaks in late spring (May-June). This is an indication that IZO is not affected by photochemical production from regional emissions in summer.

The annual course is shifted towards high values ( $>$ P75th) in spring, mid-values (P25th $<$ P $n$th $<$ P50th) in winter, and low values $(<\mathrm{P} 25$ th $)$ in autumn time, while summer contributes significantly in both low and high values (Fig. $4 \mathrm{~b}$ ). $\mathrm{ND}$ is the number of daily mean surface $\mathrm{O}_{3}$ data in each percentile range for the total period 1988-2009. $\mathrm{O}_{3}$ data above P90th are found in spring and summer whereas $\mathrm{O}_{3}$ levels below P10th are found in late summer and autumn.

\subsection{Synoptic climatology of surface $\mathrm{O}_{3}$ : transport pathways}

A previous analysis of transport pathways of $\mathrm{O}_{3}$ at $\mathrm{IZO}$ was performed by Rodríguez et al. (2004). In the present work we have incorporated a longer data series and followed a different approach, using the MCAR plots for each month for the entire surface $\mathrm{O}_{3}$ dataset (Fig. 5). This methodology does not assume a priori geographical areas, and allows us to visualize the regions from which air masses reaching IZO come with different $\mathrm{O}_{3}$ concentrations. Since at higher altitudes in the troposphere higher concentrations of $\mathrm{O}_{3}$ are expected, we have calculated the corresponding BTMH plots for each month of the year for the same period (Fig. 6).

Figure 5 shows in winter (January-March) a well-defined pattern with air masses coming from the North Atlantic and North America with a top latitude located at about $60^{\circ} \mathrm{N}$. It is also noticeable a latitudinal gradient with higher $\mathrm{O}_{3}$ values in northern regions. Concerning the height of the backward trajectories (Fig. 6), a similar latitudinal distribution to the 

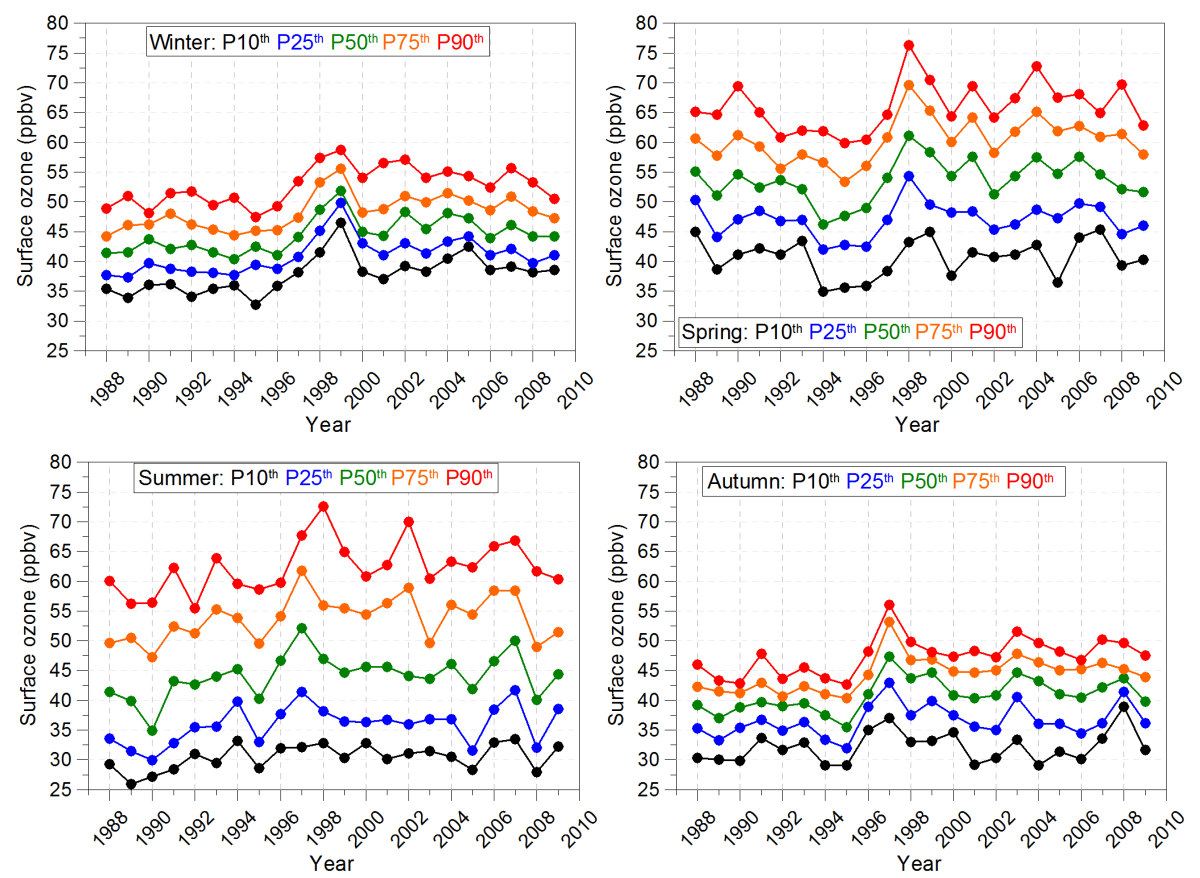

Fig. 3. Long-term (1988-2009) surface $\mathrm{O}_{3}$ concentrations (night values: 22:00-06:00 UTC) for percentiles 10th, 25th, 50th, 75th, and 90th at IZO for winter (JFM), spring (AMJ), summer (JAS) and autumn (OND).

$\mathrm{O}_{3}$ is observed, with higher altitudes to the north. The highest trajectory altitudes describe an arc-shaped corridor from Western Europe to north-eastern North America. Air masses with low $\mathrm{O}_{3}$ coming from the Sahara are also recorded associated to very low height trajectories. In spring (April-June) we observe a similar $\mathrm{O}_{3}$ pattern to winter, but with the following characteristics: (1) the latitudinal gradient is much higher, registering very high values at the northern edge of the cloud trajectories and Western Europe, describing an arcshaped pathway; (2) contributions from Sahara and southern part of the North Atlantic are lower; and (3) transport from North America is more well defined in this season. The heights of backward trajectories (Fig. 6) show a similar pattern than in winter, although the lowest trajectories from Africa travel at higher altitudes. In summer months (JulySeptember) there is a sharp change because basically only two geographical sectors of air mass pathways are identified: from North America, with associated medium and high $\mathrm{O}_{3}$ values, and from the Sahara and Northern Sahel, with a lower latitude edge set at $10-15^{\circ} \mathrm{N}$, with low and very low $\mathrm{O}_{3}$ values (Fig. 5). Air masses from North America and North Atlantic travel at relatively high altitude, whereas air masses from Sahara come from low levels (Fig. 6). It is noticeable that in July and August low-level trajectories originate from Western Sahara, while trajectories from the Sahel, and those originated over western North African countries and the Mediterranean Basin travel at mid-high altitudes. In summer time the contribution from Western Europe is at its minimum, and the highest $\mathrm{O}_{3}$ values describe an arc-shaped path- way over the North Atlantic similar to that found in spring (Fig. 5). The $\mathrm{O}_{3}$ and trajectory height patterns of autumn rapidly evolve to resemble those found in winter (Figs. 5 and 6), but with significantly lower $\mathrm{O}_{3}$ values in the southern part of the trajectories cloud.

\subsection{Low surface $\mathrm{O}_{3}$ concentrations}

The frequency distribution of trajectories by geographical sectors for low $\mathrm{O}_{3}$ values $(<\mathrm{P} 25$ th $)$ registered at IZO is shown in Fig. 7a. Air masses that most often contribute to low levels of $\mathrm{O}_{3}$ throughout the year are those from the subtropical North Atlantic (below $30^{\circ} \mathrm{N}$ ). However, in summer, especially in July and August, the Saharan air masses (with $60 \%$ frequency) are the largest contributor to $\mathrm{O}_{3}$ levels $<$ P25th. There is a secondary maximum of African air masses in March when dust layers occurring at low levels (usually within the MBL) impact IZO on their upper edge, although to a much lesser extent than in summer.

In winter very low $\mathrm{O}_{3}$ values are recorded also under fog conditions at IZO when the TIL is very high or it simply does not exist (normally with North Atlantic air masses). Hourly $\mathrm{O}_{3}$ data shows a strong negative correlation with water vapour pressure (not shown here). In summer and autumn low $\mathrm{O}_{3}$ levels are associated with the arrival of North African air masses that originate from southern Morocco, Western Sahara and Sahelian regions (25-35\% of occurrence frequency of values $<$ P10th). These trajectories show low-level $(<1500 \mathrm{~m})$ "start points", which are usually associated with 

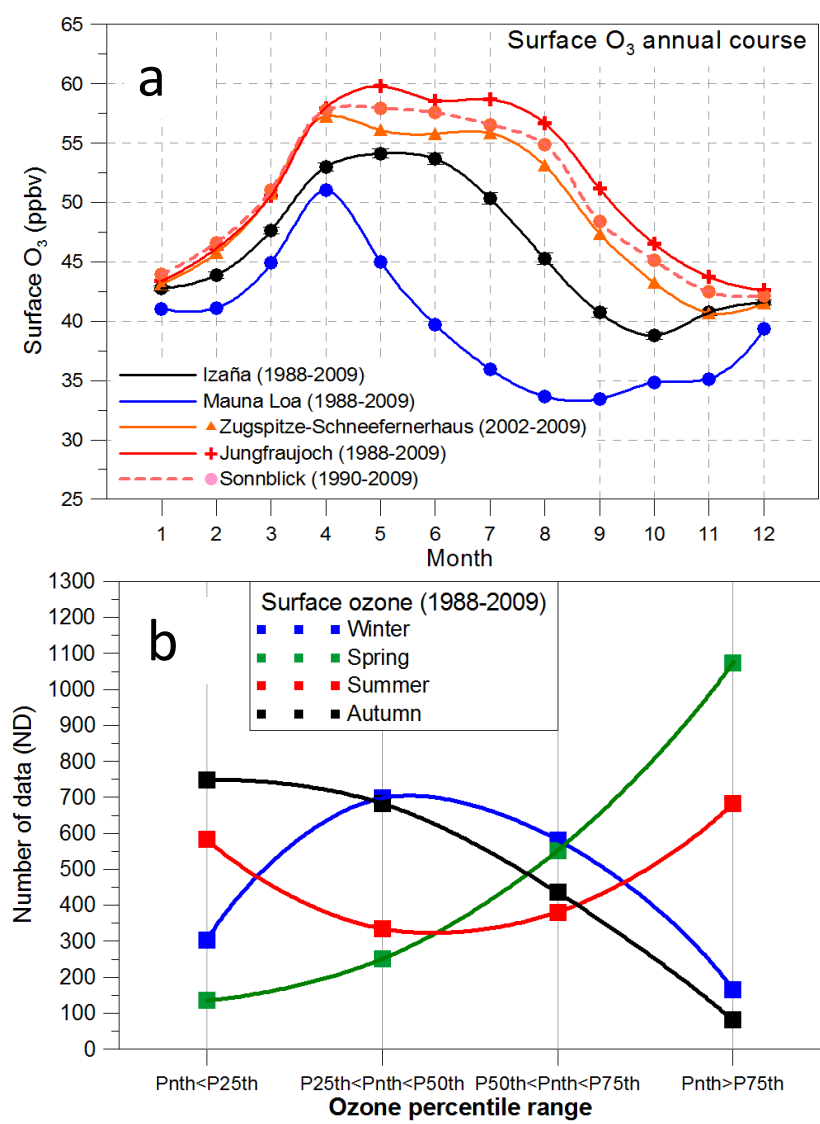

Fig. 4. (a) Annual course of surface $\mathrm{O}_{3}$ at IZO, Mauna Loa, Zugspitze-Schneefernerhaus, Jungfraujoch, and Sonnblick. Bars associated to monthly mean values at IZO are the standard deviation of the mean. (b) The seasonal distribution of number of surface $\mathrm{O}_{3}$ daily data (ND) at IZO within the following percentile ranges: P $n$th $\leq$ P10th, $\quad$ P10th $<$ P $n$th $\leq$ P25th,$\quad$ P25th $<$ P $n$th $\leq$ P50th, P50th $<$ P $n$th $\leq$ P75th, P75th $<$ P $n$th $\leq$ P90th and P $n$th $>$ P90th.

dust storms driven by surface local thermal lows over the Sahara (Prospero and Carlson, 1981).

There is a clear negative logarithmic relationship between $\mathrm{PM}_{10}$ and surface $\mathrm{O}_{3}$ in all seasons for the period 2002-2009 (Fig. 8a). Surface $\mathrm{O}_{3}$ daily nocturnal data have been grouped in $10 \mathrm{ppbv}$ bin ranges from the minimum to maximum value. Each point of the plot represents the median value of surface $\mathrm{O}_{3}$ concentrations associated to the mean value (and corresponding standard deviation of the mean) of $\mathrm{PM}_{10}$ in a determined bin range.

Most of the Saharan air masses have travelled within the African CBL, and a high percentage of them correspond to lower levels $\left(<1500 \mathrm{~m}\right.$ a.s.1.). $67 \%$ of the hourly $\mathrm{PM}_{10}$ records at IZO are lower than $10 \mathrm{\mu g} \mathrm{m}^{-3}$, and monthly means of $\mathrm{PM}_{10}$ P75th are below $10 \mu \mathrm{g} \mathrm{m}^{-3}$ through the year, except in summer time when significant $\mathrm{PM}_{10}$ concentrations are observed above P80th $\left(26 \mu \mathrm{g} \mathrm{m}^{-3}\right)$.
Bonasoni et al. (2004) found also negative correlation between surface $\mathrm{O}_{3}$ and coarse dust particles from North Africa at the high altitude Mt. Cimone station (North Italy). Andrey et al. (2010) found decreases of tropospheric $\mathrm{O}_{3}$ up to $30 \%$ in some layers, between 2 and $6 \mathrm{~km}$ altitude, during dustladen Saharan air mass intrusions over Tenerife, compared to situations of non-Sahara air masses. This result agrees with the relationship between surface $\mathrm{O}_{3}$ and $\mathrm{PM}_{10}$ found in this work.

The relationship between surface $\mathrm{O}_{3}$ and ${ }^{210} \mathrm{~Pb}$ is shown in Fig. 8b. In summer we obtain a logarithmic fit with a good correlation which resembles the $\mathrm{O}_{3}-\mathrm{PM}_{10}$ fit in the same season. Prospero et al. (1995) had reported preliminary results of $\mathrm{O}_{3}{ }^{210} \mathrm{~Pb}$ relationship for summer time. However, in spring (mainly in April) and autumn (mainly in December), when Saharan low-level intrusions over the Canary Islands occur (Alonso-Pérez et al., 2007), IZO is only slightly impacted by the top of the Saharan Air Layer (SAL). So we can see Saharan CBL signature with relatively high values of ${ }^{210} \mathrm{~Pb}$, although the $\mathrm{O}_{3}{ }^{2}{ }^{210} \mathrm{~Pb}$ relationship is not as clear as that seen in summer. In winter no correlation between surface $\mathrm{O}_{3}$ and ${ }^{210} \mathrm{~Pb}$ is found.

The low $\mathrm{O}_{3}$ values associated with African trajectories which, in turn, cause a systematic rise in relative humidity records at IZO (Cuevas, 1995), might be due to a sum of all or some of the following causes: (1) air masses come from lower levels within the Saharan CBL where $\mathrm{O}_{3}$ concentrations are generally low (Güsten et al., 1996); (2) air masses originate from similar or lower latitudes which are not enriched with the latitudinal $\mathrm{O}_{3}$ gradient existing in spring and summer in the Northern Hemisphere (London and Liu, 1992); (3) $\mathrm{O}_{3}$ might be destroyed by dry deposition on suspended dust particles because of a larger surface area to dry deposition (Güsten et al., 1996); and (4) heterogeneous removal processes on dust aerosol by nitric acid (de Reus et al., 2000).

\subsection{High surface $\mathrm{O}_{3}$ concentrations}

Figure $7 \mathrm{~b}$ shows the monthly frequency of air masses that contribute most to $\mathrm{O}_{3}$ values $>$ P75th. Air masses from North America and oceanic sectors that have travelled over the North Atlantic are the largest contributors by far to high concentrations of $\mathrm{O}_{3}$ at IZO. The highest daily $\mathrm{O}_{3}$ values (> P90th) are observed in May and June, and in the first half of summer time (July and early August). Air mass residence times associated to $\mathrm{O}_{3}$ concentrations between P75th and P90th (not shown here) show maximum values over the eastern United States (US) and North Atlantic between $30^{\circ}$ and $55^{\circ} \mathrm{N}$ in winter, over the North Atlantic, from $25^{\circ}$ to $55^{\circ} \mathrm{N}$ in spring, and near the Canary Islands and over north-western Africa in summer. In autumn the maximum residence times are much shorter and located to the northernmost position.

Summer time is very interesting since $\mathrm{O}_{3}$ records differ markedly from other seasons because the $\mathrm{O}_{3}$ concentration 

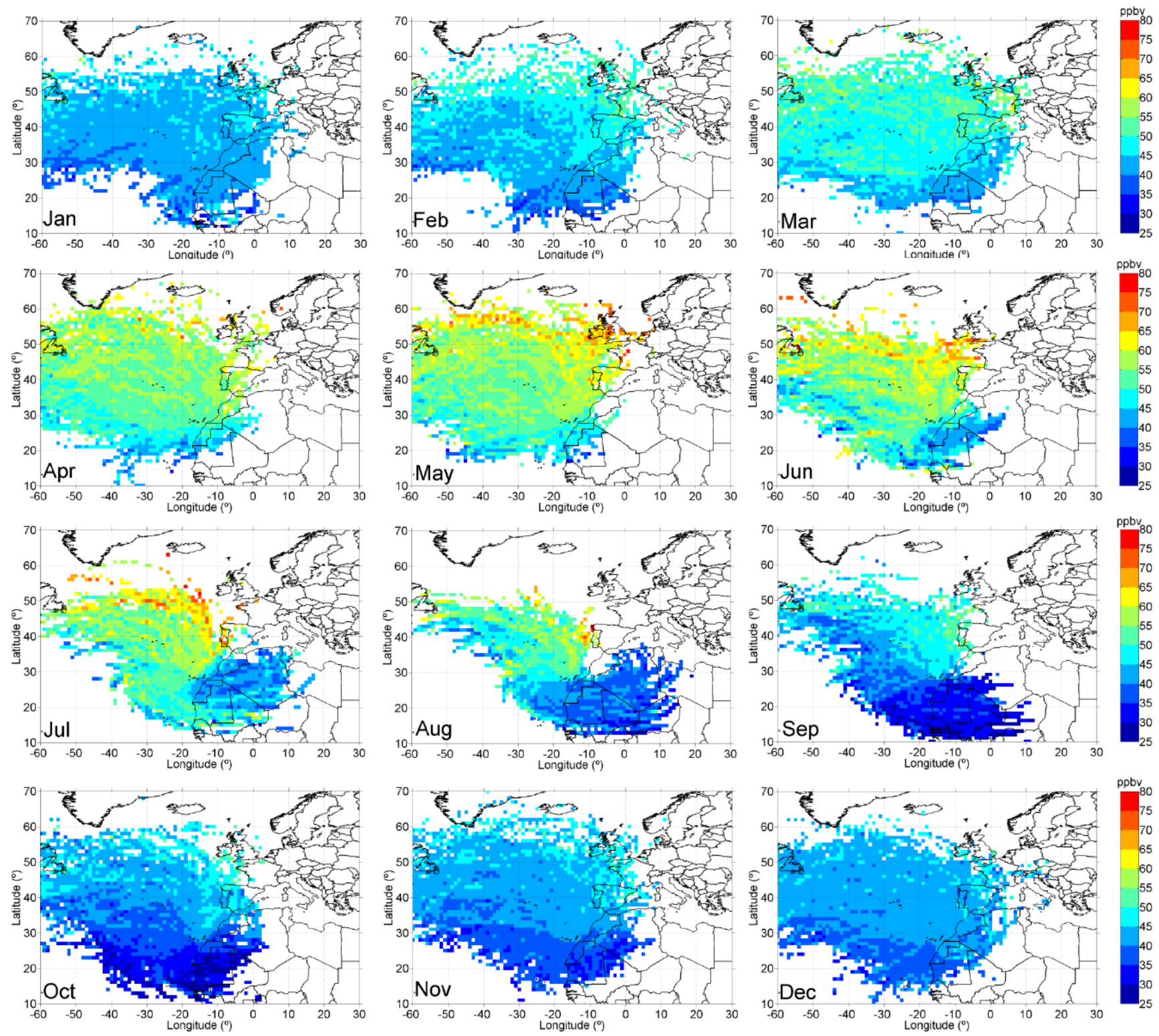

Fig. 5. Surface $\mathrm{O}_{3}$ MCAR plots for each month of the year for the period 1988-2009. Colour bars indicate $\mathrm{O}_{3}$ concentration in ppbv.

undergoes large and rapid changes (Cuevas, 1995; Rodríguez et al., 2004), often from day-to-day. The alternation of dust transport from the Saharan CBL - lasting 3-7 days - with the arrival of air masses from high levels over the North Atlantic, modulated by the Azores anticyclone, accounts for these sudden changes in $\mathrm{O}_{3}$ concentration.

\subsection{Upper troposphere contribution}

We have computed $\mathrm{PV}_{\max }$ found by daily 5-day backward trajectories when intercepting ECMWF PV-reanalysis fields for each day of the period 1988-2009. We have observed that mean values of $P V_{\max }$ in all seasons are slightly higher than $0.6 \mathrm{PVU}$. The average PV ranges approximately from
0.3 to $0.5 \mathrm{PVU}$ in the low and middle troposphere (e.g. Rao et al., 2003), while 1 PVU is a typical value of the upper troposphere. Therefore, it is noteworthy that in $10 \%$ of days in winter and autumn, backward trajectories have been impacted by upper-troposphere air masses with PV $>1$ PVU. Some of them might even have been affected by stratospheric intrusions mixed with upper-troposphere air masses.

Seasonal averages of $\mathrm{PV}_{\max }$ values have been plotted for several surface $\mathrm{O}_{3}$ bins (Fig. 9a) for winter, spring, summer and autumn. A fair $\mathrm{O}_{3}-\mathrm{PV}_{\max }$ correlation is found in all seasons with an $\mathrm{O}_{3}-\mathrm{PV}_{\max }$ slope $\sim 100 \mathrm{ppbv} \mathrm{PVU}^{-1}$ for winter, spring and summer, and a slope slightly lower $53 \mathrm{ppbvPVU}^{-1}$ for autumn. These results emphasize the 

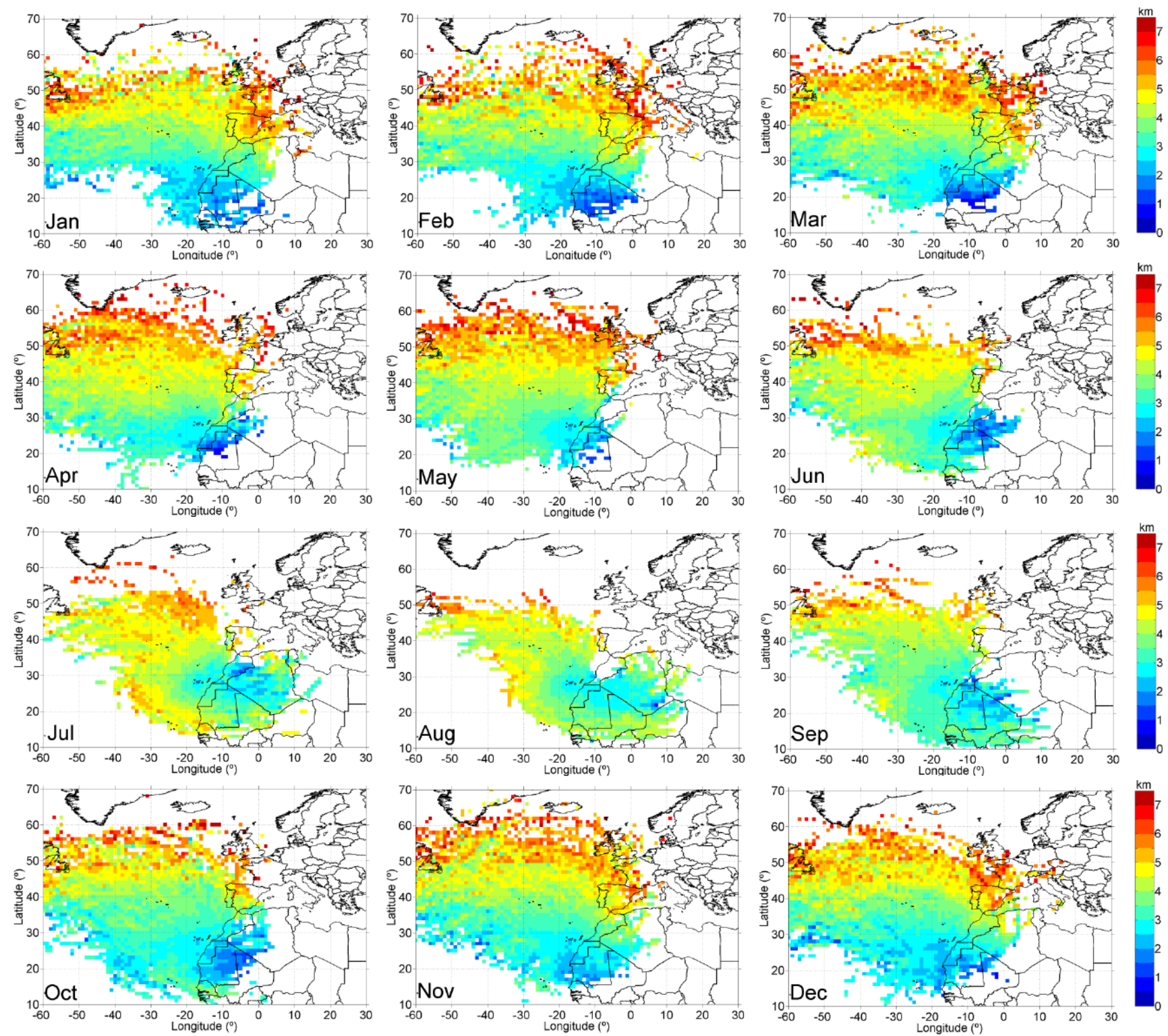

Fig. 6. Backward trajectory mean height plots for each month of the year for the period 1988-2009. Colour bars indicate height in kilometers.

importance of air mass subsidence regardless of the origin of $\mathrm{O}_{3}$ measured at IZO. Cooper et al. (2002) found over the western North Atlantic an $\mathrm{O}_{3} / \mathrm{PV}$ ratio of $\sim 72 \mathrm{ppbvPVU}^{-1}$ in spring time and $\sim 42 \mathrm{ppbvPVU}^{-1}$ in late summer/early autumn. $\mathrm{O}_{3} / \mathrm{PV}$ ratios found by Rao et al. (2003) at $500 \mathrm{hPa}$

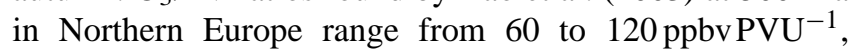
which are of the same order as the $\mathrm{O}_{3} / \mathrm{PV}_{\max }$ ratios found at IZO.

Figure 10 shows the spatial distribution of averaged $\mathrm{PV}_{\max }$ recorded by daily 5 -day backward trajectories when they are crossed with the ECMWF PV-reanalysis fields for each season. Thresholds of 1 and 1.6PVU are marked with black lines. $\mathrm{PV}_{\max }$ maps provide an estimation of geographical regions of potential STT transport. $\mathrm{PV}_{\max }$ might work as a meridional height coordinate: the highest and more northerly the air mass travels, the more $\mathrm{PV}_{\max }$ is associated. In Fig. 10 a latitudinal distribution, with much higher values of $\mathrm{PV}_{\max }$ in the north, is clearly appreciated. In mid-latitudes there is a belt with relatively high values between $45^{\circ} \mathrm{N}$ and $55^{\circ} \mathrm{N}$ that crosses the North Atlantic. This is consistent with the distribution of backward trajectory heights pattern (Fig. 6). In winter and spring this high $\mathrm{PV}_{\max }$ belt coincides with the corridor where anthropogenic pollution is exported from North America to the North Atlantic (Cooper et al., 2002; Hegarty et al., 2009), as will be discussed later on. In summer $\mathrm{PV}_{\max }$ values are substantially reduced. However, it is noticeable the relatively high $\mathrm{PV}_{\max }$ values found in the vicinity of the Canary Islands over North Africa. This result 

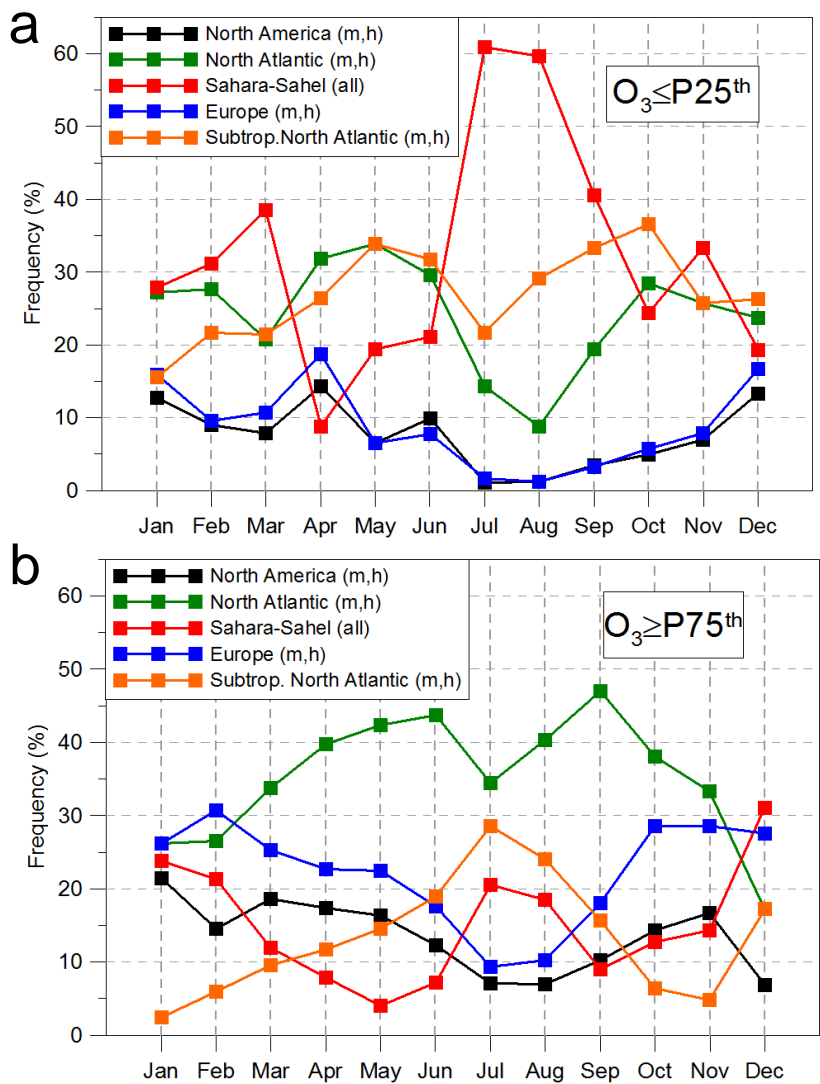

Fig. 7. (a) Monthly mean percentage of air mass types arriving to IZO for $\mathrm{O}_{3}<\mathrm{P} 25$ th for the period 1988-2009. (b) Monthly mean percentage of air mass types arriving to IZO for $\mathrm{O}_{3}>$ P75th for the period 1988-2009 (bottom panel).

is also consistent with the high altitudes of backward trajectories observed over North Africa and the Mediterranean Basin in July and August (Fig. 6).

The relationships between surface $\mathrm{O}_{3}$ and ${ }^{7} \mathrm{Be}$ are shown in Fig. $9 \mathrm{~b}$ for winter, spring, summer and autumn. The slope of $\mathrm{O}_{3}{ }_{-}{ }^{7} \mathrm{Be}$ best fit corresponding to winter is similar to the slope of $\mathrm{O}_{3}{ }^{7} \mathrm{Be}$ best fit found by Dibb et al. (unpublished manuscript, 2006; www.espo.nasa.gov/docs/intex-na/Dibb_ et_al_INTEXA.pdf) in mid and upper troposphere over North America during INTEX A flight experiment $\left(1 \mathrm{mBqm}^{-3}=\right.$ $\left.0.037 \times \mathrm{fCim}^{-3}\right)$.

Li et al. (2002b) simulated ${ }^{7} \mathrm{Be}$ and ${ }^{210} \mathrm{~Pb}$ concentrations at Tenerife for summer time and suggested that the positive $\mathrm{O}_{3}-{ }^{7} \mathrm{Be}$ and negative $\mathrm{O}_{3}{ }^{2}{ }^{210} \mathrm{~Pb}$ correlation simply reflects the respective common vertical trends. However, Cuevas (1995) and Cuevas et al. (2000) reported some case analysis of high$\mathrm{O}_{3}$ and high- ${ }^{7} \mathrm{Be}$ data associated with air mass transport from the western part of cut-off lows (COLs) developed to the west of the Iberian Peninsula in spring and summer. Rodríguez et al. (2004) have also shown that episodes of $\mathrm{O}_{3}>$ P90th at IZO are associated with strong subsidence in the FT at the western side of COLs located between the Canary Islands
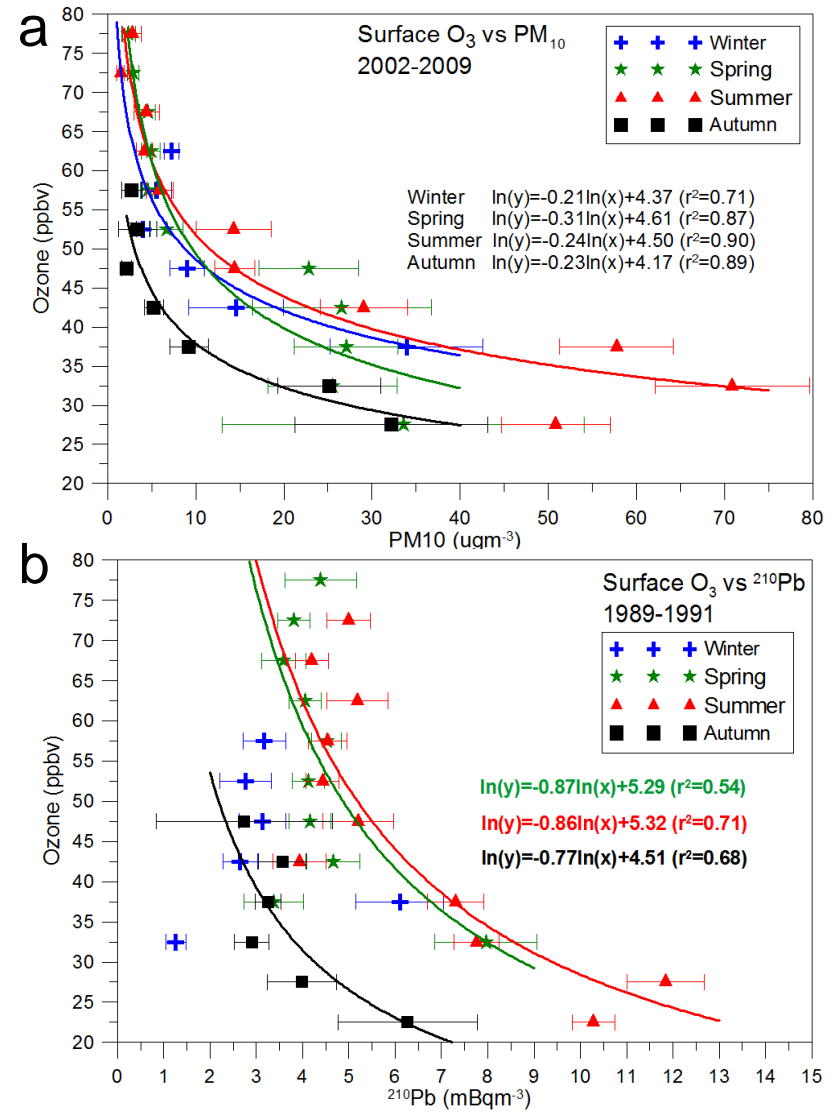

Fig. 8. (a) $\mathrm{PM}_{10}\left(\mu \mathrm{m}^{-3}\right)$ vs. surface $\mathrm{O}_{3}$ (ppbv) at IZO for winter (JFM), spring (AMJ), summer (JAS) and autumn (OND) in the period 2002-2009. (b) ${ }^{210} \mathrm{~Pb}\left(\mathrm{mBq} \mathrm{m}^{-3}\right)$ vs. surface $\mathrm{O}_{3}$ (ppbv) for the same seasons in the period 1988-1991. Surface $\mathrm{O}_{3}$ daily nocturnal data have been grouped in $10 \mathrm{ppbv}$ bin ranges from the minimum to maximum value. Each point of the plot represents the median value of surface $\mathrm{O}_{3}$ concentrations associated to the mean values of $\mathrm{PM}_{10}$ or ${ }^{210} \mathrm{~Pb}$ in a determined bin range. The standard deviation of the mean (SDOM) associated to $\mathrm{PM}_{10}$ and ${ }^{210} \mathrm{~Pb}$ mean values is represented by horizontal bars.

and the Iberian Peninsula. The STT processes are frequently associated to COL developments in the subtropical North Atlantic (Kentarchos et al., 2000). Cuevas and Rodríguez (2002), with an 11-yr climatology of ECMWF isentropic potential vorticity fields, concluded that the frequency of COLs and deep lows over the North Atlantic reach a maximum in May-July, in areas surrounding the Iberian Peninsula where these lows are more frequent. James et al. (2003), with a 15yr climatology of STT exchange found similar results, concluding that the corridor parallel to the Atlantic coast of the Iberian Peninsula over the ocean down to the Canaries frequently receives stratospheric air.

Reiter et al. (1983) suggested a ${ }^{7} \mathrm{Be}$ threshold value of $8 \mathrm{mBqm}^{-3}$, above which an air mass probably has stratospheric signature. This value has been used by several 

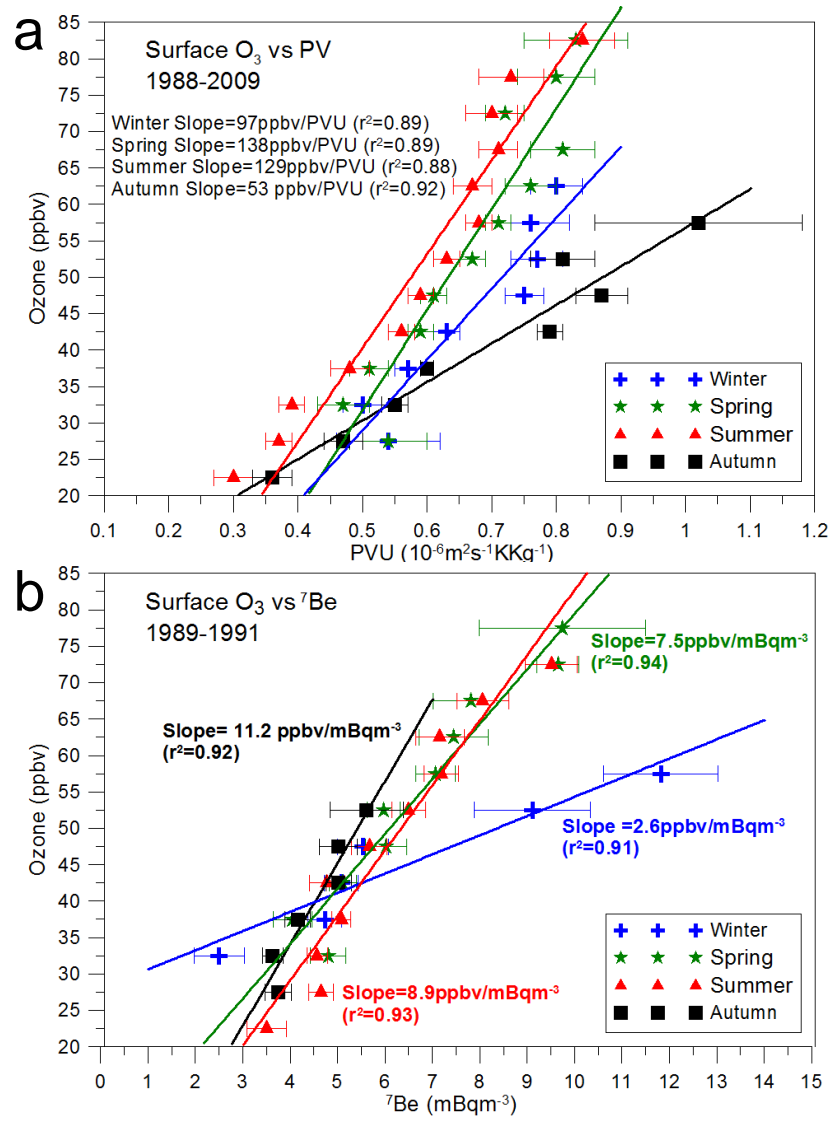

Fig. 9. (a) $\mathrm{PV}_{\max }\left(1 \mathrm{PVU}=10^{-6} \mathrm{~m}^{2} \mathrm{~s}^{-1} \mathrm{KKg}^{-1}\right)$ vs. surface $\mathrm{O}_{3}$ (ppbv) at IZO for winter (JFM), spring (AMJ), summer (JAS) and autumn (OND) in the period $1988-2009$. (b) ${ }^{7} \mathrm{Be}\left(\mathrm{mBqm}^{-3}\right)$ vs. $\mathrm{O}_{3}$ ozone (ppbv) at IZO for the same seasons in the period 1989-1991. Data have been grouped and depicted as for Fig. 8.

authors to identify stratospheric intrusions in high mountain stations (Zanis et al., 1999; Stohl et al., 2000; Bonasoni et al., 2000; Cristofanelli et al., 2006), although it is not possible to consider ${ }^{7} \mathrm{Be}$ as an unambiguous stratospheric tracer (Zanis et al., 1999; Stohl et al., 2000). Gerasopoulos et al. (2001) found at four high-altitude alpine stations that high ${ }^{7} \mathrm{Be}$ values (above $6 \mathrm{mBqm}^{-3}$ ) correspond to air masses from the north and high altitudes, as it is characteristic for stratospheric intrusions. Reiter et al. (1983) showed that the range of ${ }^{7} \mathrm{Be}$ values $>7.4 \mathrm{mBqm}^{-3}$ corresponds to direct stratospheric intrusions near the station, without a long advection path. The third quartile of ${ }^{7} \mathrm{Be}$ data series at IZO is $8.2 \mathrm{mBq} \mathrm{m}^{-3}$, and stratospheric air mass intrusions normally reach the ground after considerable mixing with tropospheric air. Therefore, a threshold value of $8 \mathrm{mBqm}^{-3}$ is reasonable to estimate the impact of UTLS air masses at IZO.

We have estimated the impact on $\mathrm{O}_{3}$ at IZO of air masses with daily mean values of ${ }^{7} \mathrm{Be}>8 \mathrm{mBqm}^{-3}$. Results are summarized in Table 3. The percentage of cases per season
Table 3. Basic statistics of surface $\mathrm{O}_{3}$ at IZO for days with daily ${ }^{7} \mathrm{Be}>8 \mathrm{mBqm}^{-3}$. The term "climat." refers to the $\mathrm{O}_{3}$ mean when considering all the ozone values within the indicated period independently of the ${ }^{7} \mathrm{Be}$ value.

\begin{tabular}{lcccc}
\hline $\mathrm{O}_{3}$ (ppbv) & Winter & Spring & Summer & Autumn \\
\hline \%cases & 3.8 & 14.6 & 8.9 & 1.4 \\
Mean & $47.8 \pm 1.9$ & $60.3 \pm 1.4$ & $56.8 \pm 2.2$ & $46.3 \pm 4.1$ \\
Median & 45.0 & 59.4 & 56.8 & 42.3 \\
Climat. & $44.7 \pm 0.3$ & $53.6 \pm 0.4$ & $45.5 \pm 0.5$ & $40.4 \pm 0.3$ \\
\hline
\end{tabular}

with ${ }^{7} \mathrm{Be}>8 \mathrm{mBqm}^{-3}$ is significant in spring and summer $(14.6 \%$ and $8.9 \%$ of cases/season, respectively), while in winter and autumn the percentage of cases/season is much lower ( $3.8 \%$ and $1.4 \%$, respectively). The impact of high ${ }^{7} \mathrm{Be}$ events on $\mathrm{O}_{3}$ values at IZO is considerable, recording in these events $\mathrm{O}_{3}$ averages that are $7 \mathrm{ppbv}$ and $11 \mathrm{ppbv}$ above $\mathrm{O}_{3}$ climatological values (considering all days independently of ${ }^{7} \mathrm{Be}$ values) for spring and summer, respectively.

We have plotted the residence time of air masses with daily ${ }^{7} \mathrm{Be}>8 \mathrm{mBqm}^{-3}$ for each season of the year in Fig. 11 . Higher residence times are observed in mid-latitudes over the north-eastern US extending over the North Atlantic in winter. In spring several maximum residence times are observed over the North Atlantic, but a maximum which extends along a north-south corridor over the eastern North Atlantic stretching from Great Britain to the Canary Islands is notable. Similar results were obtained by Rodríguez et al. (2004) for $\mathrm{O}_{3}$ values within P50th-P100th in spring. In summer the corridor is strengthened to the vicinity of the Canary Islands, and a secondary maximum is found in north-eastern North America extending over North Atlantic. In autumn this maximum is also identified, and some secondary high residence times near the Canary Islands are observed. In relation to the height at which air masses were travelling, it is noteworthy that in the spring and summer they come from altitudes above $5 \mathrm{~km}$. To summarize, the source regions of high ${ }^{7} \mathrm{Be}$ air masses with maximum impact on $\mathrm{O}_{3}$ at IZO are registered in a region around the Canaries extending to the north over North Atlantic in spring and summer. This region coincides with areas where COL developments and STT processes have been reported in previous studies (e.g. Cuevas and Rodríguez, 2002; James et al., 2003; Rodríguez et al., 2004). Nieto et al. (2005), from a 41-yr climatology of COLs in the Northern Hemisphere, reported three preferred areas of COLs occurrence, one of them being the southern European and the eastern Atlantic coast, in agreement with our results.

Recently, Hegarty et al. (2009) revealed that $\mathrm{O}_{3}$ observations from TES (Tropospheric Emission Spectrometer) also evidence stratospheric intrusions associated with the cyclones over the North Atlantic. According to Wernli and Bourqui (2002), "deep exchange" denotes events where air parcels are rapidly transported from the stratosphere down to levels below $700 \mathrm{hPa}$ level (deep STT). The STT climatology 

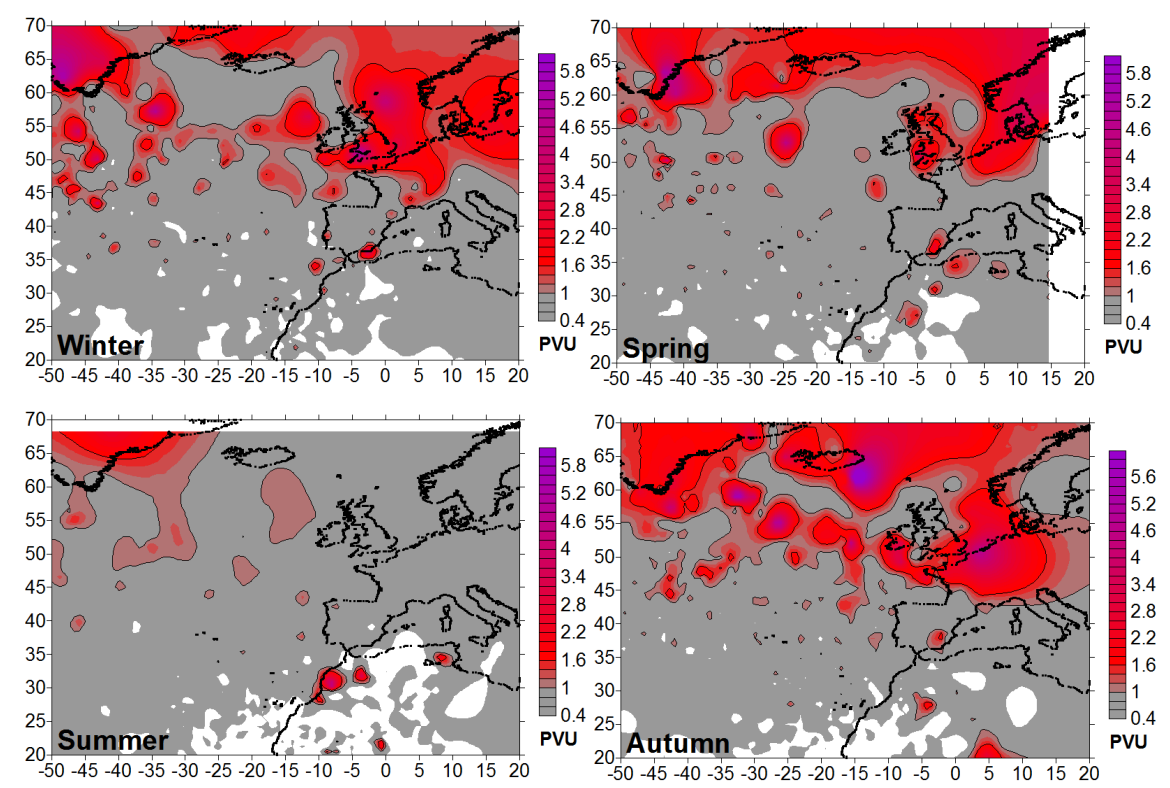

Fig. 10. $\mathrm{PV}_{\max }$ maps for winter (JFM), spring (AMJ), summer (JAS) and autumn (OND) in the period 1988-2009. They have been constructed from the coordinates of $\mathrm{PV}_{\max }$ values found by 5-day backward trajectories arriving at IZO every day at 00:00 UTC in ECMWF PV-reanalysis fields. Thresholds of 1 and 1.6 PVU are marked with black lines.

from Sprenger and Wernli (2003) shows that deep STT is particularly strong in the $40-65^{\circ} \mathrm{N}$ latitude band over the North Atlantic storm track region in winter, just in the high $\mathrm{PV}_{\max }$ passageway we have found in this season (Fig. 10).

\subsection{Relationship between $\mathrm{O}_{3}$ and $\mathrm{CO}$}

Hegarty et al. (2009) reported that composites of $\mathrm{O}_{3}$ and $\mathrm{CO}$ retrievals from TES showed the main pollution export from North America extended in a band from $30^{\circ} \mathrm{N}$ to $45^{\circ} \mathrm{N}$. Strong positive correlations between $\mathrm{CO}$ and surface $\mathrm{O}_{3}$ are found in maritime stations off the coast of Canada (Kasibhatla et al., 1996). These positive correlations are attributed to the transport of photochemically generated $\mathrm{O}_{3}$ from North America out over the North Atlantic (Parrish et al., 1993).

The concentration of $\mathrm{CO}$ at IZO shows a general increase during autumn and winter until the maximum is reached in late March, while the minimum is observed in middle August (Gómez-Peláez et al., 2012). The relationships between surface $\mathrm{O}_{3}$ and $\mathrm{CO}$ at $\mathrm{IZO}$ for each season of the year are shown in Fig. 12. The good correlation between $\mathrm{O}_{3}$ and $\mathrm{CO}$ at IZO in winter (with an $\mathrm{O}_{3} / \mathrm{CO}$ slope of $0.84 \mathrm{ppbvppv}^{-1}$ ), in spring when surface $\mathrm{O}_{3}$ is within $30-50$ ppbv and $\mathrm{CO}$ within 85-115 pbbv (with an $\mathrm{O}_{3} / \mathrm{CO}$ slope of $0.91 \mathrm{ppbvppv}^{-1}$ ), and in autumn with an $\mathrm{O}_{3} / \mathrm{CO}$ slope of $0.81 \mathrm{ppbvppbv}^{-1}$ for surface $\mathrm{O}_{3}$ values below 35 ppbv, supports the hypothesis of long-range transport of photochemically generated $\mathrm{O}_{3}$ to IZO in these seasons, likely from North America according to the paths of the trajectories (Fig. 5). However, the lack of correlation between surface $\mathrm{O}_{3}$ and $\mathrm{CO}$ found in summer suggests that significant $\mathrm{O}_{3}$ enhancements are not directly caused by long-range transport of anthropogenic pollution in this season. These results agree with $\mathrm{Li}$ et al. (2002b) who found the strongest export of anthropogenic $\mathrm{CO}$ from North America in winter, and the weakest in summer.

Chin et al. (1994) found an $\mathrm{O}_{3} / \mathrm{CO}$ slope $\sim 0.3 \mathrm{ppbvppv}^{-1}$ in aged air masses at rural sites in eastern North America. Hegarty et al. (2009) found that, under some meteorological conditions, some cyclones near the east coast of the US produced the greatest export to the lower FT with $\mathrm{O}_{3}>65 \mathrm{ppbv}$ and a well-defined $\mathrm{O}_{3}-\mathrm{CO}$ correlation with an $\mathrm{O}_{3} / \mathrm{CO}$ slope $\sim 0.20 \mathrm{ppbvppbv}^{-1}$, indicative of the overall impact of photochemical processes in North American continental export. However, Honrath et al. (2004) reported for the high mountain station of Pico in Azores, in the middle of the North Atlantic, that $\mathrm{O}_{3}$ and $\mathrm{CO}$ were correlated during North American outflow events, with a slope averaging $1.0 \mathrm{ppbvpbv}^{-1}$ - more than $80 \%$ larger than $\mathrm{O}_{3} / \mathrm{CO}$ ratios observed in the eastern US and near-shore outflow region. Honrath et al. (2004) explained these high ratios by the fact that air masses from North American outflow events have undergone days of photochemical processing, increasing the $\mathrm{O}_{3} / \mathrm{CO}$ ratio.

A 3-yr "climatology" of daily $\mathrm{O}_{3} / \mathrm{CO}$ ratios is shown in Table 4. Mean ( \pm standard deviation), median, P25th and P75th of $\mathrm{O}_{3} / \mathrm{CO}$ ratios have been calculated for each season. The highest concentrations of $\mathrm{CO}$ at IZO ( $>133 \mathrm{ppbv}$, above the P90th) are observed in winter and spring, mostly coming 

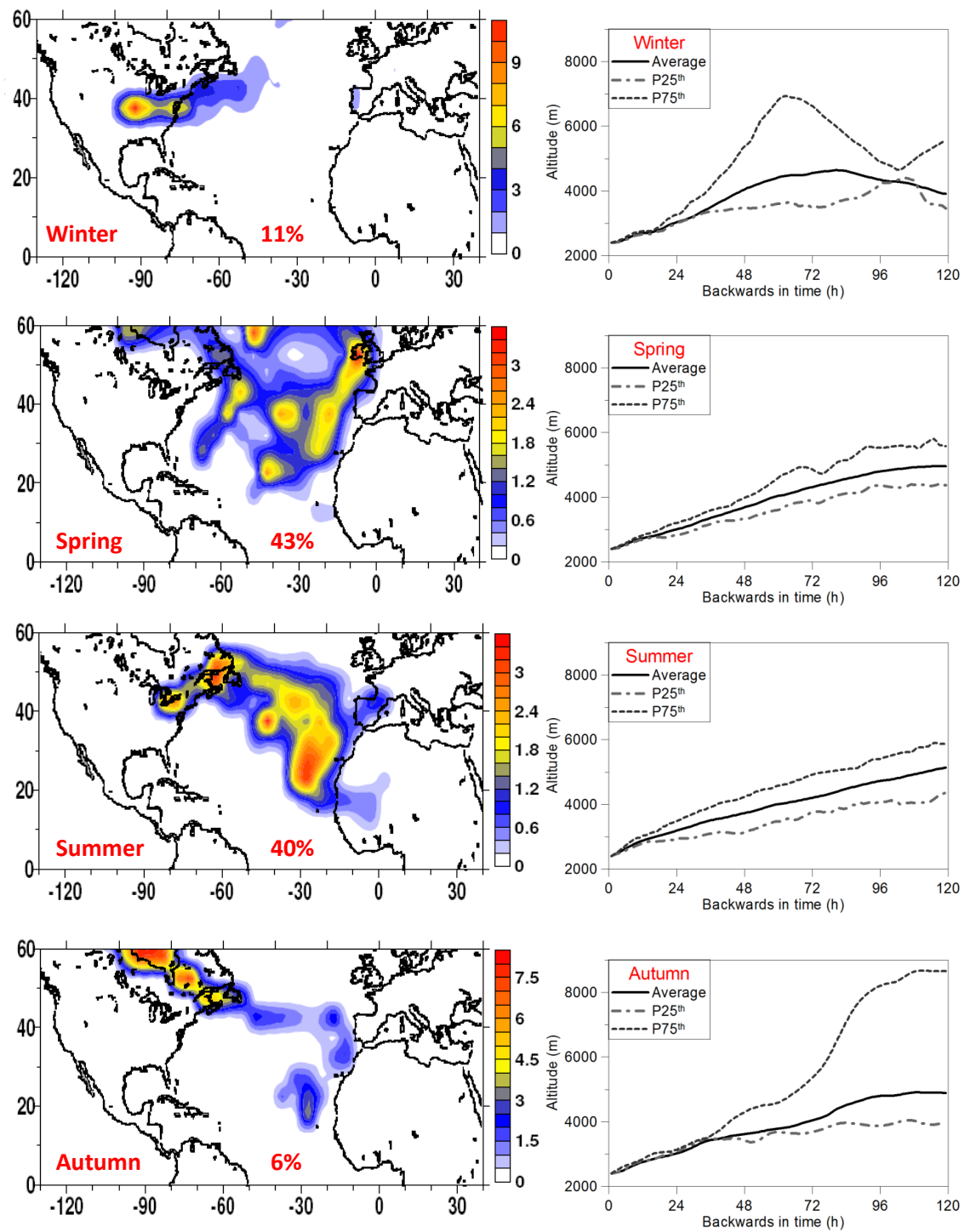

Fig. 11. Residence times and transport pathways of air masses with daily ${ }^{7} \mathrm{Be}>8 \mathrm{mBqm}^{-3}$ and corresponding averaged backward trajectories heights for each season of the year. Colour bars indicate the residence time in arbitrary units. In backward trajectory heights the mean values P25th and P75th are plotted.

from North America (not shown here). In order to determine the impact of long-range transport of American pollution, and the origin of the fairly good $\mathrm{O}_{3}-\mathrm{CO}$ correlation, we have analyzed the events in which, at least during five consecutive days, a good correlation $(r>0.75)$ between hourly concentrations of $\mathrm{O}_{3}$ and $\mathrm{CO}$ is observed within the period 20082011. We have separated the events in five groups according to $\mathrm{O}_{3}$ ranges and seasons. The $\mathrm{O}_{3} / \mathrm{CO}$ ratios are summarized in Table 5. In winter the events Type 1 and Type 2 show $\mathrm{O}_{3} / \mathrm{CO}$ ratios of 0.41 and 0.43 ppbv ppbv $^{-1}$, respectively, which lie within the climatological median-P100th $\mathrm{O}_{3} / \mathrm{CO}$ range for this season (Table 4). The events with the highest $\mathrm{O}_{3} / \mathrm{CO}$ values $\left(0.53 \pm 0.07 \mathrm{ppbvppbv}^{-1}\right)$ were recorded in spring, all of them for $\mathrm{O}_{3}>$ P75th (Type 3) being within the climatological P25th-P75th $\mathrm{O}_{3} / \mathrm{CO}$ range for $\mathrm{O}_{3}>\mathrm{P} 75$ th (Table 4). In summer the only 7-day event recorded (Type 4) showed a mean $\mathrm{O}_{3} / \mathrm{CO}$ ratio of $0.67 \mathrm{ppbvppbv}^{-1}$, which is lower than the climatological mean for $\mathrm{O}_{3}>$ P75th (Table 4). In autumn events of high $\mathrm{O}_{3}-\mathrm{CO}$ correlation, associated to long-range transport, were also recorded (Type 5), but the averaged $\mathrm{O}_{3} / \mathrm{CO}$ ratio $\left(0.45 \pm 0.04 \mathrm{ppbvppbv}^{-1}\right)$ is lower than the climatological mean for this season.

As demonstrated in Table 5, most of the events showing a good correlation between $\mathrm{O}_{3}$ and $\mathrm{CO}$, and thus unambiguous transport of likely anthropogenic $\mathrm{O}_{3}$, are observed in spring and winter. Thus, a residence time analysis of air masses with an $\mathrm{O}_{3}-\mathrm{CO}$ correlation $>0.75$ has been performed for these two seasons (Fig. 13a). The results 


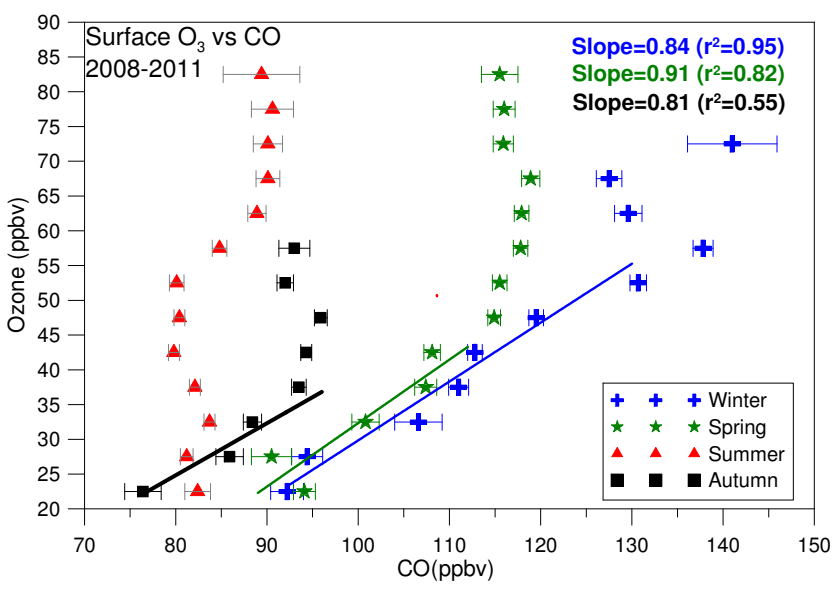

Fig. 12. $\mathrm{CO}$ (ppbv) vs. surface $\mathrm{O}_{3}$ (ppbv) at IZO for winter (JFM), spring (AMJ), summer (JAS) and autumn (OND) in the period of 2008-2011. Data have been grouped and depicted as for Fig. 8.

Table 4. Averaged $\mathrm{O}_{3} / \mathrm{CO}$ ratios $\left(\mathrm{ppbv} p p b v^{-1}\right)$ at $\mathrm{IZO}$ for winter, spring, summer and autumn (all cases and those with $\mathrm{O}_{3}>\mathrm{P} 75$ th), and estimated type of air mass ( $\mathrm{FP}=$ Fresh Pollution; $\mathrm{A}=$ Aged air mass; UT $=$ Upper Troposphere). Types of air masses have been labelled according to the $\mathrm{O}_{3} / \mathrm{CO}$ range values.

\begin{tabular}{lccccc}
\hline & Mean \pm SD & Median & P25th & P75th & Type \\
\hline Winter & $0.39 \pm 0.07$ & 0.38 & 0.34 & 0.44 & FP \\
$\mathrm{O}_{3}>$ P75th & $0.42 \pm 0.06$ & 0.40 & 0.37 & 0.45 & FP \\
\hline Spring & $0.47 \pm 0.10$ & 0.46 & 0.40 & 0.53 & $\mathrm{~A}$ \\
$\mathrm{O}_{3}>$ P75th & $0.58 \pm 0.10$ & 0.56 & 0.51 & 0.62 & $\mathrm{~A}+\mathrm{UT}$ \\
\hline Summer & $0.56 \pm 0.15$ & 0.55 & 0.44 & 0.65 & $\mathrm{~A}+\mathrm{UT}$ \\
$\mathrm{O}_{3}>$ P75th & $0.71 \pm 0.13$ & 0.70 & 0.61 & 0.78 & $\mathrm{~A}+\mathrm{UT}$ \\
\hline Autumn & $0.47 \pm 0.10$ & 0.47 & 0.41 & 0.54 & $\mathrm{~A}$ \\
$\mathrm{O}_{3}>$ P75th & $0.54 \pm 0.08$ & 0.54 & 0.49 & 0.60 & $\mathrm{~A}+\mathrm{UT}$ \\
\hline
\end{tabular}

identify a main contribution from pollution episodes over North America in winter, with backward trajectory heights below $4 \mathrm{~km}$, whereas in spring aged air masses (previously transported from North America) are found over North Atlantic at slightly higher altitudes (above $4-5 \mathrm{~km}$ ), although it must be stated that there is substantial overlap in the ranges of altitude of both seasons (Fig. 13a and b). In both cases maximum residence times are observed over the eastern US and western North Atlantic, on a corridor bounded by the parallels $20^{\circ}$ and $50^{\circ} \mathrm{N}$. High trajectories suggest that pollution was injected previously over the US east coast into the FT. These results agree with previous studies in which the warm conveyor belt associated with cyclonic pressure systems lifts $\mathrm{O}_{3}$ produced photochemically in the CBL up into the FT over eastern continental US, and then the $\mathrm{O}_{3}$ is transported by the westerlies across the North Atlantic onto Europe (Berkowtiz et al., 1996; Stohl and Trickl, 1999; Cooper and Parrish, 2004).
Table 5. $\mathrm{O}_{3} / \mathrm{CO}$ ratios at IZO for events with hourly $\mathrm{O}_{3}-\mathrm{CO}$ data correlation $r>0.75$

\begin{tabular}{llll}
\hline & $\begin{array}{l}\mathrm{O}_{3} \text { range } \\
(\mathrm{ppbv})\end{array}$ & $\begin{array}{l}\mathrm{O}_{3} / \mathrm{CO} \\
\left(\mathrm{ppbv} \mathrm{ppbv}^{-1}\right)\end{array}$ & Cases (2008-2011) \\
\hline Type 1 & P50th-P75th & $0.41 \pm 0.03$ & 8 in winter \\
Type 2 & P75th-P100th & $0.43 \pm 0.07$ & 5 in winter \\
Type 3 & P75th-P100th & $0.53 \pm 0.07$ & 58 in spring \\
Type 4 & P75th-P100th & $0.67 \pm 0.14$ & 7 in summer \\
Type 5 & P75th-P100th & $0.45 \pm 0.04$ & 7 in autumn \\
\hline
\end{tabular}

In winter the $\mathrm{O}_{3} / \mathrm{CO}$ ratios found during long-range transport events $\left(\sim 0.42 \mathrm{ppbvppbv}^{-1}\right)$ agree quite well with the climatological ratio for this season. The ratios do not differ substantially from those calculated for high $\mathrm{O}_{3}$ values (> P75th) and from those obtained for all values of $\mathrm{O}_{3}$ for the study period. So, in winter, when the westerlies blow with their maximum intensity, $\mathrm{O}_{3}$ measured at IZO might have a large contribution of long-range pollution transport from North America. The $\mathrm{O}_{3} / \mathrm{CO}$ ratios reported near the pollution sources range from 0.2 to $0.3 \mathrm{ppbvppbv}^{-1}$ (e.g. Chin et al., 1994; Dickerson et al., 1995; Li et al., 2002b; Hegarty et al., 2009). The higher ratios found at IZO imply an additional $\mathrm{O}_{3}$ amount and/or $\mathrm{CO}$ reduction which may arise, in part, from photochemical processing during transporting. In these conditions we could consider that the transport events labelled Type 1 and Type 2 (Table 5) correspond to fresh pollution that is transported rapidly from North America to the subtropical FT. In spring the climatological $\mathrm{O}_{3} / \mathrm{CO}$ ratios differ notably if we consider $\mathrm{O}_{3}$ values $>\mathrm{P} 75$ th $\left(\sim 0.58 \mathrm{ppbv} \mathrm{ppbv}^{-1}\right)$ or all $\mathrm{O}_{3}$ values $\left(\sim 0.47 \mathrm{ppbv} \mathrm{ppbv}^{-1}\right)$. The average ratio found in pollution transport events labelled Type $3\left(\sim 0.53 \mathrm{ppbvppbv}^{-1}\right)$ is between these two values. This may be due to the fact that in spring a higher insolation speeds up in situ photochemistry in the FT (Yienger et al., 1999), and also to large-scale downward transport of $\mathrm{O}_{3}$-rich air from the upper troposphere. Thus, $\mathrm{O}_{3} / \mathrm{CO}$ ratios between 0.47 and $0.54 \mathrm{ppbv} \mathrm{ppbv}^{-1}$ might be typical of aged air masses originating in North America, while ratios above $0.54 \mathrm{ppbv}_{\mathrm{ppbv}}{ }^{-1}$ might be explained by a mix of aged air masses and upper troposphere $\mathrm{O}_{3}$-rich air masses. These assumptions are consistent with the analysis of residence times and heights of air masses characterized by high $\mathrm{O}_{3}-\mathrm{CO}$ correlation (Fig. 13a). In spring air masses come normally from higher altitudes than in winter, and the maximum of air masses residence times is located north-east of the maximum found in winter, over western and central North Atlantic, further from pollution sources. On the other hand the seasonal averaged $\mathrm{O}_{3} / \mathrm{CO}$ slopes $\left(0.84 \mathrm{ppbv} \mathrm{ppbv}^{-1}\right.$ for winter and $0.91 \mathrm{ppbv} \mathrm{ppbv}^{-1}$ for spring; see Fig. 12), which include all kinds of $\mathrm{O}_{3}$ production and transport processes are higher than the $\mathrm{O}_{3} / \mathrm{CO}$ ratios found in well-identified, long-range pollution transport $\left(0.42-0.53 \mathrm{ppbv} \mathrm{ppbv}^{-1}\right)$, suggesting the contribution of a second source of $\mathrm{O}_{3}$. The corridor of North 

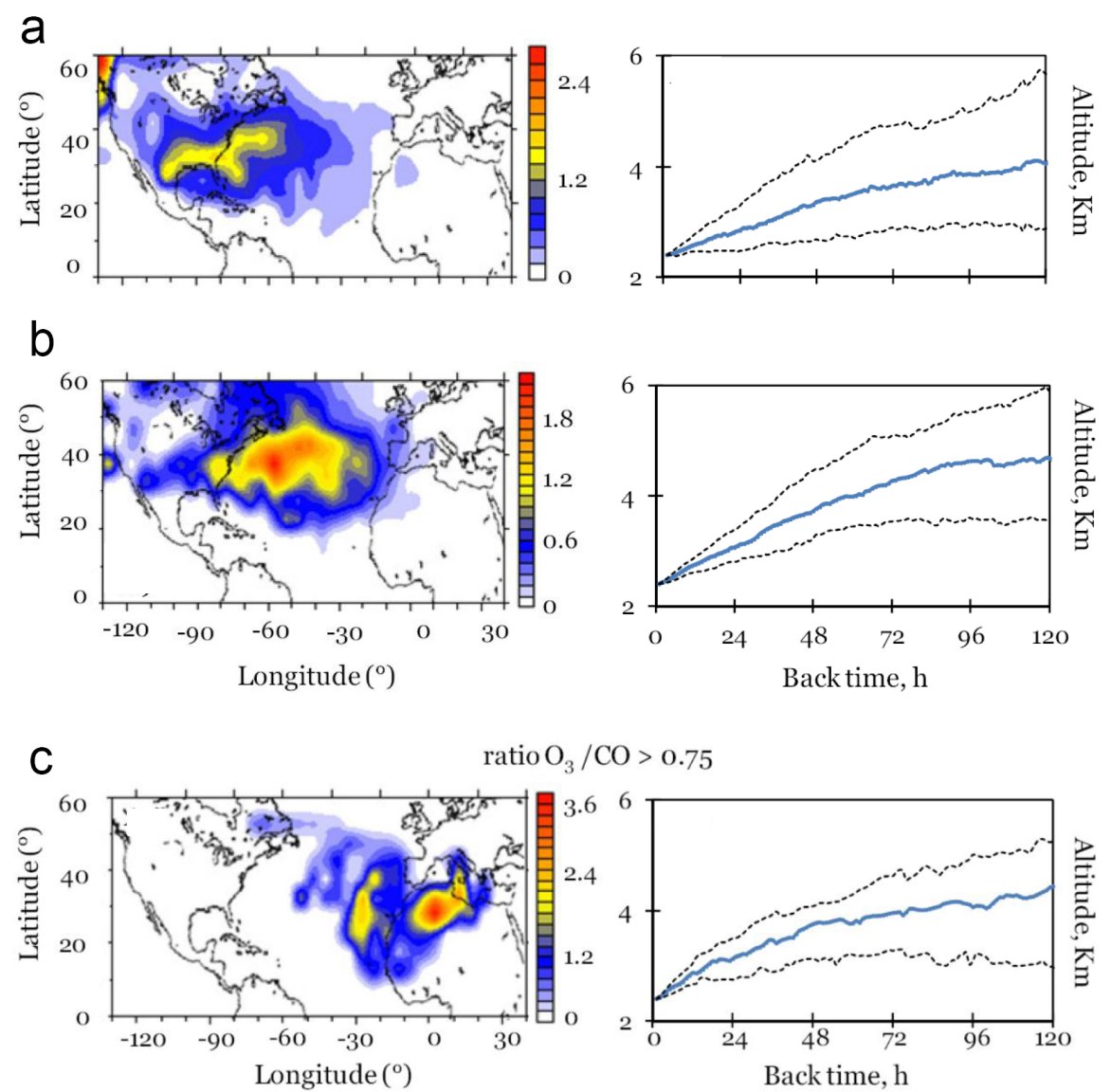

Fig. 13. Residence time of air masses (corrected by central convergence) that show an $\mathrm{O}_{3}-\mathrm{CO}$ hourly correlation $r>0.75$ for winter and spring (a, b). Colour bars indicate residence time in arbitrary units. Mean, P25th and P75th of 5-day backward air masses travelling altitude for these events in winter and spring are depicted. (c) Residence time of air masses that show an $\mathrm{O}_{3} / \mathrm{CO}$ hourly ratio $>0.75 \mathrm{ppbv} p \mathrm{pbv}^{-1}$, and corresponding averaged backward trajectories height.

American pollution events (Cooper et al., 2002; Hegarty et al., 2009) overlaps to a large extent the belt with relatively high $\mathrm{PV}_{\max }$ values found in winter and spring between $45^{\circ}$ and $55^{\circ} \mathrm{N}$, crossing the North Atlantic (Fig. 10). Differences found between the $\mathrm{O}_{3} / \mathrm{CO}$ ratios at $\mathrm{IZO}$ and seasonal $\mathrm{O}_{3} / \mathrm{CO}$ slopes, on the one hand, and between the latter with $\mathrm{O}_{3} / \mathrm{CO}$ ratios near the pollution sources, on the other hand, could be explained with the following conceptual model based on two processes: (1) $\mathrm{O}_{3}$ continued to be produced in the plume during transportation in the FT (Honrath et al., 2004; Mao et al., 2006); and (2) contribution from the upper-level air transported downward in the descending dry airstream of cyclones over the North Atlantic, which may have enhanced the lower tropospheric $\mathrm{O}_{3}$ keeping levels high (Hegarty et al., 2009). Bearing in mind that high $\mathrm{O}_{3}$ values at IZO are normally associated to high-altitude backward trajectories - high-PV and high- ${ }^{7} \mathrm{Be}$ values - this conceptual model might conciliate the apparently contradictory results of finding simultaneous positive $\mathrm{O}_{3}-\mathrm{CO}$ correlation (Fig. 12), on the one hand, and positive $\mathrm{O}_{3}-\mathrm{PV}$ (Fig. 9a) and $\mathrm{O}_{3}{ }^{7} \mathrm{Be}$ (Fig. 9b) corre- lations, on the other hand, in winter and spring. Therefore, a mixture of photochemical $\mathrm{O}_{3}$ produced as a result of pollution export from North America and $\mathrm{O}_{3}$ from stratospheric intrusions over the North Atlantic into the FT seems to be a likely process. This result agrees with Hegarty et al. (2009) who highlighted that some frequent meteorological patterns could produce a well-stirred region of the atmosphere over the North Atlantic that continuously interleaves air masses originating from the lower mid- and upper troposphere, and thus favouring the mixing of polluted air masses with stratospheric $\mathrm{O}_{3}$-rich air masses.

Concerning high $\mathrm{O}_{3}$ values recorded at IZO in summer time some authors (e.g. Schmitt and Carretero, 1992; Raes et al., 1997; Li et al., 2002b) hypothesized that, under some conditions during the summer, pollutants and photochemically-produced $\mathrm{O}_{3}$ can be transported to the $\mathrm{Ca}$ nary Islands from the Iberian Peninsula and adjacent regions in Europe. Such conditions would be favoured by a coupled system consisting of the Iberian thermal low at ground level and anticyclonic subsidence aloft (Millán et al., 1997). 
However, this transport is most likely to occur within the MBL and not in the FT, as stated by Stohl et al. (2002) who analyzed the southward flow of European pollution in summer over the Mediterranean Basin and North Africa. The MCAR plots of $\mathrm{O}_{3}$ pathways (Fig. 5) do not show significant transport of $\mathrm{O}_{3}$ from Europe, and there is no relationship between $\mathrm{O}_{3}$ and $\mathrm{CO}$ (Fig. 12). These results suggest a low probability of occurrence of pollution transport from Europe within the subtropical FT over the North Atlantic. These results agree with Duncan and Bey (2004) who concluded that there was no evidence of a summer time $\mathrm{CO}$ maximum at IZO in either the observations or the model simulations they performed for IZO. Concerning potential pollution from North America, we have found a single 7-day long-range transport pollution event at Izana in this season. Owen et al. (2006) documented that, on average, $38 \%$ of the North American CO export occurs below $3 \mathrm{~km}$ altitude, and that advection of pollution layers at low levels, but decoupled from the BML, is responsible for the majority of transport to the central North Atlantic during summer time. However, in summer air masses arriving to IZO from the North Atlantic show a strong subsidence (see Fig. 6), most of them travelling at levels higher than $3 \mathrm{~km}$. Moreover, aged air masses from North America that recirculate, turning around the Azores high anticyclonically (Auvray and Bey, 2005), are decoupled from the air mass pathways to IZO for the same reason. This may be the explanation for finding lower $\mathrm{O}_{3} / \mathrm{CO}$ ratios at IZO than at the Azores Pico station.

The climatological $\mathrm{O}_{3} / \mathrm{CO}$ ratios at IZO in summer time are significantly higher: $0.56 \mathrm{ppbv} \mathrm{ppbv}^{-1}$ if we consider the whole dataset, and 0.71 ppbv ppbv $^{-1}$ for $\mathrm{O}_{3}>$ P75th (P75th $\mathrm{O}_{3} / \mathrm{CO}$ ratio $\sim 0.78 \mathrm{ppbvppbv}^{-1}$ ). We have analyzed all the episodes in which $\mathrm{O}_{3} / \mathrm{CO}$ ratio $>0.75 \mathrm{ppbv} \mathrm{ppbv}^{-1}$. In these cases $\mathrm{O}_{3}$ does not correlate with $\mathrm{CO}\left(\mathrm{O}_{3}-\mathrm{CO}\right.$ correlation $<0.1$ ). We have identified 41 cases in the period 2008-2011, $10 \%$ of them in spring and $90 \%$ in summer. The median value of the relative humidity associated to these events was $12 \%$, so very dry air suggesting a mid-upper troposphere origin. The residence time analysis shows two predominant origins of the air masses arriving at IZO (Fig. 13b): one located over North Africa and the central Mediterranean Basin, and the other one in a corridor stretching from the Canary Islands to the west of the Iberian Peninsula. These air masses come from altitudes higher than $4 \mathrm{~km}$, showing a strong subsidence. All these events are associated with COL or deep low developments, which indicates they come from the upper troposphere and likely could be influenced by STT processes. The geographical origin of these events agrees with the $P V_{\max }$ distribution over North Africa (Fig. 10), and the maximum residence time distribution of air masses with ${ }^{7} \mathrm{Be}>8 \mathrm{mBqm}^{-3}$ (Fig. 11). These results also agree with $\mathrm{Ni}$ eto et al. (2005) who identified North Africa and the Mediterranean Basin (centred over the Italian Peninsula), and the corridor between the Canary Islands and the west of the Iberian
Peninsula as main areas of occurrence of COLs in summer time in the Northern Hemisphere.

\subsection{The role of the NAO in tropospheric $\mathrm{O}_{3}$ budget over the subtropical North Atlantic}

The large swing in the phase of the NAO between 1995 and 1996 brought international attention to the physical connection between the NAO and e.g. availability of water in Scandinavia for hydropower generation (Hurrell et al., 2003). Indeed, changes in time series pattern have also been observed in surface $\mathrm{O}_{3}$ records at IZO between 1996 and 1998 (Fig. 3). Logan et al. (2012) show a significant change in monthly mean time series of surface ozone at the alpine stations in 1997. These changes cannot be attributed to changes in $\mathrm{O}_{3}$ precursors, but to dynamical processes.

Positive phases of NAO indicate stronger Azores high and stronger Icelandic low and thus more active westerlies over the North Atlantic above $50^{\circ} \mathrm{N}$. However, in lower midlatitudes and in the subtropical North Atlantic, winter positive phases of NAO mean less zonal west-to-east transport. Positive NAO also implies drier conditions than average over northern Africa and a strong subtropical high pressure over the North Atlantic resulting in an increase of dust mobilization through strengthening of trade winds over the Sahara (Chiapello et al., 2005; Evan et al., 2006), and higher frequency of dust intrusions over the subtropical North Atlantic, and specifically over the Canaries (Alonso-Pérez et al., 2011). As we have shown in previous sections, Saharan air masses loaded with mineral dust are associated with low concentrations of surface $\mathrm{O}_{3}$ at IZO. The negative phase of NAO results in a higher flow of westerlies in the range $30^{\circ}-$ $45^{\circ} \mathrm{N}$, as can be derived from the circulation patterns over the North Atlantic under positive and negative phases of the NAO shown by Hurrel and Dickson (2004).

Figure 14 shows the correlation between NAO and the zonal component of the wind $(u)$ at $700 \mathrm{hPa}$ (NCEP reanalysis) in winter, spring, summer and autumn for the entire period 1988-2009. A strong negative correlation is found in winter and autumn within the $20-40^{\circ} \mathrm{N}$ belt, with a weaker correlation in spring. These results indicate a more effective air mass transport from North America to the Canaries within the low mid- and subtropical latitude belts (between $20^{\circ}$ and $40^{\circ} \mathrm{N}$ ) with negative phase of NAO. Hence, this "transport belt" appears to be more active over the subtropical North Atlantic during negative phases of NAO in winter and spring. The effect of intercontinental transport is expected to be weaker in summer ( $\mathrm{Li}$ et al., 2002a).

Hurrell et al. (2003) concluded that, generally, positive NAO phase winters are associated with a north-eastward shift in the Atlantic storm activity. These results agree with the findings of Andrade et al. (2008), who reported that the interannual correlation between the enlarged winter (October to March) NAO index and the total number of storms observed in the Azores Islands is negative and statistically significant. 
Table 6. Mean surface $\mathrm{O}_{3}$ for $\mathrm{NAO}>+0.5$ and $\mathrm{NAO}<-0.5$ for each season in the period 1988-2009 with the corresponding standard deviation of the mean. The third column shows the confidence level for the difference between the means.

\begin{tabular}{|c|c|c|c|}
\hline & $\begin{array}{c}\mathrm{A} \\
\mathrm{NAO}>+0.5\end{array}$ & $\begin{array}{c}\mathrm{B} \\
\mathrm{NAO}<-0.5\end{array}$ & Confidence Level \\
\hline Winter & $\begin{array}{l}42.9 \pm 0.3 \\
(n=605)\end{array}$ & $\begin{array}{l}45.2 \pm 0.3 \\
(n=349)\end{array}$ & $100.0 \%$ \\
\hline Spring & $\begin{array}{l}51.4 \pm 0.5 \\
(n=440)\end{array}$ & $\begin{array}{l}53.9 \pm 0.6 \\
(n=362)\end{array}$ & $99.9 \%$ \\
\hline Summer & $\begin{array}{c}44 \pm 0.7 \\
(n=366)\end{array}$ & $\begin{array}{l}46.3 \pm 0.6 \\
(n=456)\end{array}$ & $98.8 \%$ \\
\hline Autumn & $\begin{array}{c}40.3 \pm 0.3 \\
(n=368)\end{array}$ & $\begin{array}{c}40.8 \pm 0.3 \\
(n=537)\end{array}$ & $76.2 \%$ \\
\hline
\end{tabular}

Sprenger and Wernli (2003) found that that there is a strong relationship between the negative phase of NAO and cyclone frequency across the North Atlantic, and specifically that during the negative phase of NAO the low tropospheric destination of the deep STT extends over a large region of the North Atlantic below the $40^{\circ} \mathrm{N}$ parallel, covering the Canary Islands. Nieto et al. (2000) reported that during positive NAO years, a high occurrence of COLs is detected for all the longitudes from $70^{\circ} \mathrm{N}$ to about $44^{\circ} \mathrm{N}$, while during negative $\mathrm{NAO}$ years this high density of COLs is detected on a band from $60^{\circ} \mathrm{N}$ to $35^{\circ} \mathrm{N}$ over the North Atlantic, so shifted southwards and, consequently, most likely to influence the subtropical region of the North Atlantic.

Creilson et al. (2003), using TOR data, found that the latitude band of greatest tropospheric $\mathrm{O}_{3}$ was in the central mid-latitudes $\left(35-40^{\circ} \mathrm{N}\right)$ and not the upper latitudes (40$45^{\circ} \mathrm{N}$ ). In Fig. 15 we have plotted the averaged TOR in winter (January-March) and spring (April-June) for years with $\mathrm{NAO}>+0.5$ and for years with $\mathrm{NAO}<-0.5$, as well as the corresponding ozone relative differences between negative and positive NAO phases for each season. It is noteworthy that in winter a negative phase of NAO results in higher tropospheric $\mathrm{O}_{3}$ amounts over most of the geographical domain of our study, and clearly over the Eastern North Atlantic. These results agree with Pausata et al. (2012), who found an increase of few ppbv of surface $\mathrm{O}_{3}$ concentrations in stations of the western part of the Iberian peninsula in winter under negative phase of NAO, corresponding to the increase of TOR as can be seen in Fig. 15e. In spring with a negative phase of NAO, there is a significant increment in tropospheric $\mathrm{O}_{3}(\sim 10 \% ; 5$ Dobson Units) in a band that stretches across the eastern North Atlantic (over the Canaries), North Africa, the western Mediterranean basin, and southern countries of Eastern Europe. The relationship between TOR and NAO breaks down in summer and autumn when the westerlies are not so strong (Creilson et al., 2003).

These results are confirmed by our analysis using surface $\mathrm{O}_{3}$ at IZO (Table 6). In years with $\mathrm{NAO}<-0.5$ surface $\mathrm{O}_{3}$ is systematically higher than in years with $\mathrm{NAO}>+0.5$ in all seasons. However, the highest differences between the two phases of NAO are observed in spring $(\sim 3 \mathrm{ppbv})$, and the lowest in autumn ( $\sim 1 \mathrm{ppbv})$. The confidence level of $\mathrm{O}_{3}$ differences is higher than $99 \%$ for winter and spring. We can see in Fig. 16 that a significant change in air mass frequencies after 1996 is observed. For example, a considerable reduction in frequency of African air masses associated with $\mathrm{O}_{3}<\mathrm{P} 25$ th, and a significant increase in frequency of air masses associated with $\mathrm{O}_{3}>$ P75th from North America and North Atlantic are registered in winter at IZO. In winters with negative phases of NAO, a more active jet stream and a higher frequency of storms over the North Atlantic within the $30-45^{\circ} \mathrm{N}$ belt are observed, resulting in a stronger transport west-to-east of potentially polluted air masses from US and major impact of storms over this belt. This is a probable explanation to the sharp increase observed in the $\mathrm{O}_{3}$ record between 1996 and 1998 (Fig. 3). This is in agreement with the flattening in surface $\mathrm{O}_{3}$ series observed at European stations since the late 1990s (e.g. Ordóñez et al., 2007; Gilge et al., 2010; Logan et al., 2012).

\section{Summary/conclusions}

A detailed analysis of a high-quality, long-term (22-yr) surface $\mathrm{O}_{3}$ time series (1988-2009) at the subtropical high mountain IZO station has been conducted. Diurnal and seasonal $\mathrm{O}_{3}$ variations have been assessed. Surface $\mathrm{O}_{3}$ diurnal variations show the lowest values during the afternoon mainly due to an efficient dry deposition on the mountain slopes. The annual mean difference between the daily upslope and the downslope surface $\mathrm{O}_{3}$ values ranges from 2 to 5 ppbv. The amplitude and width of the diurnal $\mathrm{O}_{3}$ "valley" is basically modulated by two factors: the solar radiation, and the consequent heating of the slopes surrounding the observatory, and the synoptic wind strength.

Daily nocturnal (22:00-06:00 UTC) $\mathrm{O}_{3}$ values have been analyzed for the entire record. The average yearly mean $\mathrm{O}_{3}$ value at IZO for the $22 \mathrm{yr}$ period is $46.1 \mathrm{ppbv}$ and the peak-to-peak annual cycle amplitude is $15.4 \mathrm{ppbv}$. There is a slight positive trend in the annual mean $\left(0.19 \pm 0.05 \% \mathrm{yr}^{-1}\right.$ or $0.09 \mathrm{ppbv} \mathrm{yr}^{-1}$ ). There is a notable increase in $\mathrm{O}_{3}$ observed between 1996 and 1998. Seasonal $\mathrm{O}_{3}$ cycles show a broad maximum beginning in late spring (May), with frequent daily means of 60-70 ppbv. The annual minimum is found in October with $\mathrm{O}_{3}$ values often falling in the range $30-45$ ppbv.

An analysis of the climatology of $\mathrm{O}_{3}$ pathways using backward trajectories showed that higher $\mathrm{O}_{3}$ values are associated with air masses travelling above $4 \mathrm{~km}$ altitude from North America and the North Atlantic Ocean, while low $\mathrm{O}_{3}$ is transported from the Saharan CBL, largely corresponding to transport at lower altitudes $(<1500 \mathrm{~m}$ a.s.l. $)$.

An extensive review of the potential $\mathrm{O}_{3}$ production and transport processes into the FT of the North Atlantic subtropical region has been presented, incorporating other 

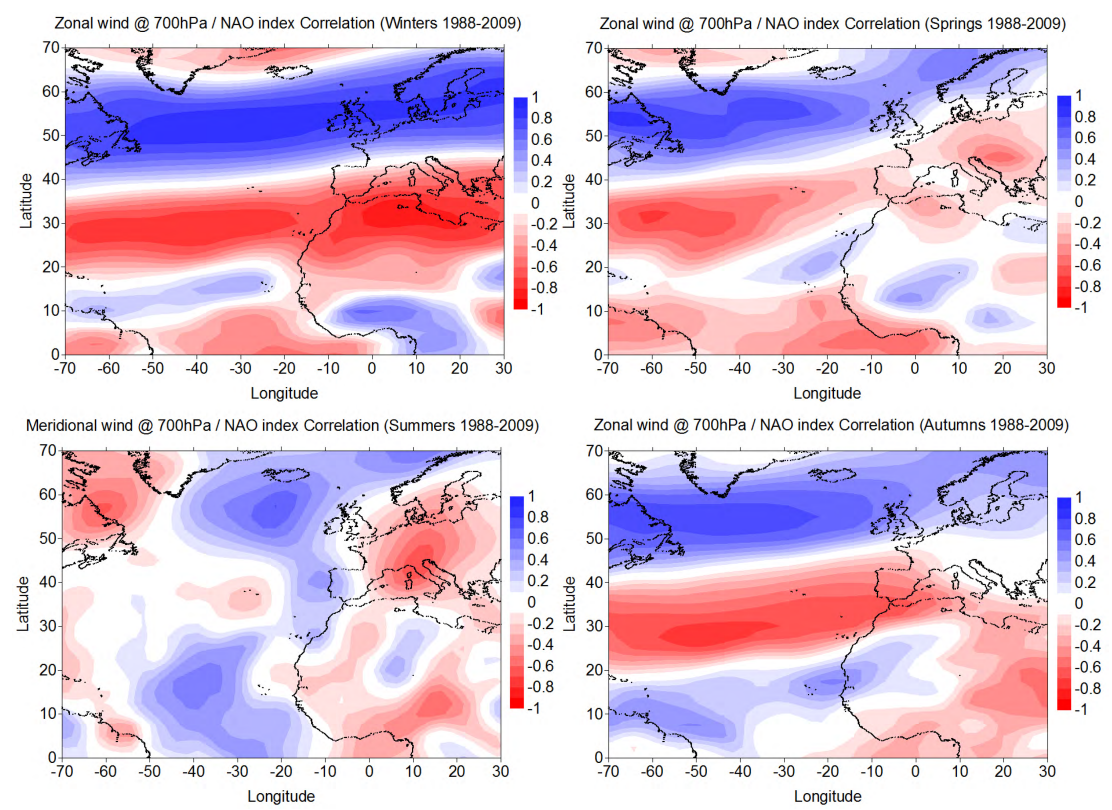

Fig. 14. Correlation between zonal wind component $(u)$ at $700 \mathrm{hPa}$ and NAO-index in winter (JFM), spring (AMJ), summer (JAS) and autumn (OND) for the period 1988-2009.

measurements from the IZO station such as $\mathrm{PM}_{10}, \mathrm{CO},{ }^{7} \mathrm{Be}$, ${ }^{210} \mathrm{~Pb}$, and additional information from backward trajectories and PV. A clear negative logarithmic relationship was observed between $\mathrm{PM}_{10}$ and surface $\mathrm{O}_{3}$ for all seasons. A similar relationship was found between $\mathrm{O}_{3}$ and ${ }^{210} \mathrm{~Pb}$.

A positive correlation between $\mathrm{O}_{3}$ and $\mathrm{PV}_{\max }$, and between $\mathrm{O}_{3}$ and ${ }^{7} \mathrm{Be}$ is found throughout the year, indicating that relatively high surface $\mathrm{O}_{3}$ values at IZO originate from the middle troposphere and in some cases from the upper troposphere. Spatial analyses of $\mathrm{PV}_{\max }$ show a belt with relatively high values between $45^{\circ}$ and $55^{\circ} \mathrm{N}$ crossing the North Atlantic. In winter and spring this high $\mathrm{PV}_{\max }$ belt coincides with the corridor where anthropogenic pollution is exported from North America to the North Atlantic. In summer the relatively high $\mathrm{PV}_{\max }$ values found in the vicinity of the Canary Islands over North Africa are notable. The impact of high ${ }^{7} \mathrm{Be}$ events on $\mathrm{O}_{3}$ values at IZO is considerable; $\mathrm{O}_{3}$ averages recorded during these events are $7 \mathrm{ppbv}$ and $11 \mathrm{ppbv}$ above climatological values for spring and summer, respectively. Residence time analysis of air masses with daily ${ }^{7} \mathrm{Be}>8 \mathrm{mBq} \mathrm{m}^{-3}$ (threshold value above which an air mass has stratospheric signature) showed a region around the Canaries extending to the north over North Atlantic in spring and summer. This region coincides with areas where COL developments and STT processes have been reported in previous studies.

The influence of long-range pollution transport events on $\mathrm{O}_{3}$ levels has been studied using $\mathrm{CO}$ data. At IZO a good correlation between $\mathrm{O}_{3}$ and $\mathrm{CO}$ in winter (with an $\mathrm{O}_{3} / \mathrm{CO}$ slope of $0.84 \mathrm{ppbvpbv}^{-1}$ ) and in spring, when surface $\mathrm{O}_{3}$ is within $30-50 \mathrm{ppbv}$ and $\mathrm{CO}$ within $85-115 \mathrm{pbbv}$ (with an $\mathrm{O}_{3} / \mathrm{CO}$ slope of $0.91 \mathrm{ppbv} \mathrm{ppbv}^{-1}$ ) is observed. This supports the hypothesis of long-range transport of photochemically generated $\mathrm{O}_{3}$ from North America. In order to determine the impact of long-range transport of American pollution events, we observed and analyzed, within the period of 2008-2011, those days in which there were at least five consecutive days with a good correlation $(r>0.75)$ between hourly concentrations of $\mathrm{O}_{3}$ and $\mathrm{CO}$. These events presented the highest $\mathrm{O}_{3} / \mathrm{CO}$ ratios $\left(0.53 \pm 0.09 \mathrm{ppbvppbv}^{-1}\right)$ in spring. In winter this ratio was lower $\left(\sim 0.42 \mathrm{ppbv} p p b v^{-1}\right)$ and agrees quite well with the climatological ratio for this season. The time residence analysis highlights a main contribution from pollution episodes over North America in winter, whereas in spring the origin of the air masses are identified over North America as well over North Atlantic at high altitudes. So, in winter, when the westerlies blow with their maximum intensity, and to a lesser extent in spring, $\mathrm{O}_{3}$ measured at IZO might be affected by long-range pollution transport from North America.

Differences found between the daily $\mathrm{O}_{3} / \mathrm{CO}$ ratios at IZO and seasonal $\mathrm{O}_{3} / \mathrm{CO}$ slopes, and between the latter with $\mathrm{O}_{3} / \mathrm{CO}$ ratios near the pollution sources could be explained with the following conceptual model based on two processes: (1) $\mathrm{O}_{3}$ continued to be produced in the plume during its transport in the FT; and (2) contribution from the upper-level air transported downward in the descending dry airstream of cyclones over the North Atlantic, which may have enhanced the lower tropospheric $\mathrm{O}_{3}$ keeping levels high. This conceptual model conciliates the apparently contradictory re- 

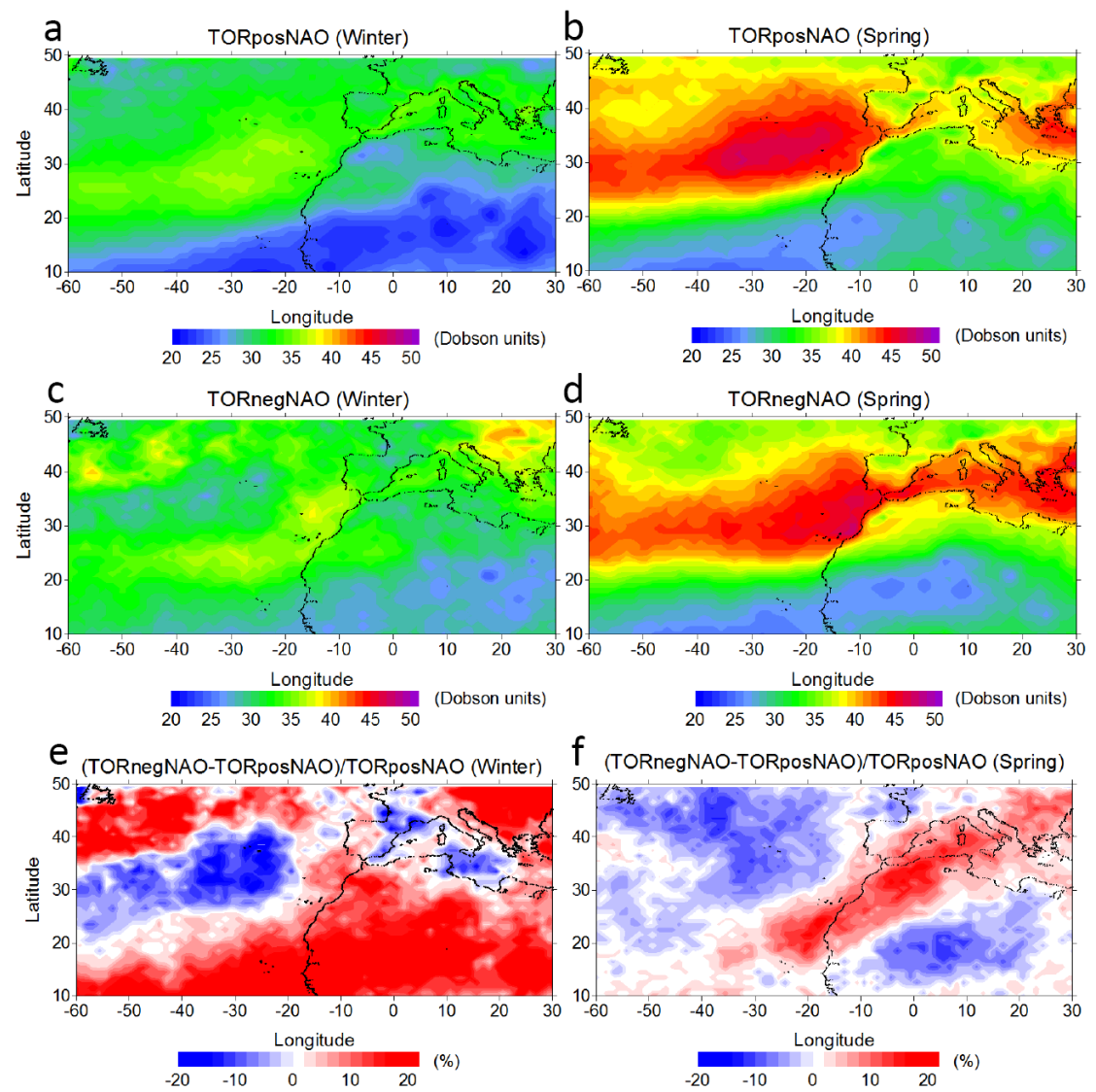

Fig. 15. Averaged tropospheric ozone residual (TOR) data (in Dobson units) in winter (JFM) and spring (AMJ) for years with NAO $>+0.5$ $(\mathbf{a}, \mathbf{b})$ and for years with NAO $<-0.5(\mathbf{c}, \mathbf{d})$. Percentage differences between TOR with negative NAO, and TOR with positive NAO in winter and spring, respectively (e, f).

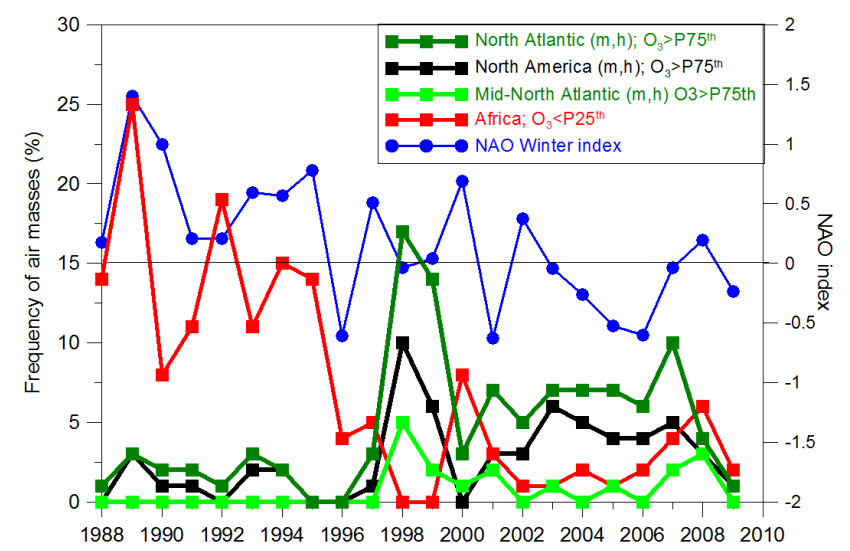

Fig. 16. Long term frequency of air masses arriving to IZO from Africa sector associated with $\mathrm{O}_{3}<\mathrm{P} 25$ th, and from North Atlantic and North America associated with $\mathrm{O}_{3}>$ P75th in winter. NAO index for winter is also shown. sults of finding simultaneous positive $\mathrm{O}_{3}-\mathrm{CO}$ correlation and positive $\mathrm{O}_{3}-\mathrm{PV}_{\max }$ and $\mathrm{O}_{3}-{ }^{7} \mathrm{Be}$ correlations in winter and spring. So, a mixture of photochemical $\mathrm{O}_{3}$ produced as a result of pollution export from North America and "natural" $\mathrm{O}_{3}$ from stratospheric intrusions over the North Atlantic into the FT seems to be a likely process. In summer the MCAR plots of $\mathrm{O}_{3}$ pathways do not show significant transport of $\mathrm{O}_{3}$ from Europe, and no relationship between $\mathrm{O}_{3}$ and $\mathrm{CO}$ is also found. These results suggest a low probability of occurrence of pollution transport from Europe within the subtropical FT over the North Atlantic. We have analyzed all the episodes in which $\mathrm{O}_{3} / \mathrm{CO}$ ratio $>0.75 \mathrm{ppbv}_{\mathrm{ppbv}}{ }^{-1}$. In these cases, $10 \%$ of them in spring and $90 \%$ in summer, $\mathrm{O}_{3}$ does not correlate with $\mathrm{CO}\left(\mathrm{O}_{3}-\mathrm{CO}\right.$ correlation $\left.<0.1\right)$.

The residence time analysis of air masses with $\mathrm{O}_{3}>\mathrm{P} 75$ th shows two main origins: one located over North Africa and the central Mediterranean Basin, and the other one in a corridor stretching from the Canary Islands to the west of the Iberian Peninsula. These air masses come from altitudes higher than $4 \mathrm{~km}$ and show a strong subsidence. All these events are associated with COL or deep-low developments, which indicates they are caused by STT processes. 
The geographical origin of these events agree with the $\mathrm{PV}_{\max }$ distribution over North Africa and the maximum residence time distribution of air masses with ${ }^{7} \mathrm{Be}>8 \mathrm{mBqm}^{-3}$.

Taking into account all $\mathrm{O}_{3}-\mathrm{CO}$ relationships found at IZO and in other studies, we propose the following approach concerning the origin of $\mathrm{O}_{3}$ at IZO. Fresh Pollution $\mathrm{O}_{3}$ from North America, mainly observed in winter, might be associated with $\mathrm{O}_{3} / \mathrm{CO}$ ratios between $\sim$ 0.34 and $\sim 0.4$ ppbvppbv $^{-1} . \mathrm{O}_{3} / \mathrm{CO}$ ratios within $\sim 0.40$ $0.55 \mathrm{ppbv} \mathrm{ppbv}^{-1}$ range likely correspond to aged air masses originated in North America and North Atlantic, in winter, spring and autumn. Aged air masses in combination with inputs from the upper troposphere observed in spring, summer and autumn might be identified by $\mathrm{O}_{3} / \mathrm{CO}$ ratios from $\sim 0.55$ to $0.62 \mathrm{ppbv} \mathrm{ppbv}^{-1}$. In summer time high $\mathrm{O}_{3}$ values are associated with $\mathrm{O}_{3} / \mathrm{CO}$ ratios $>0.65 \mathrm{ppbv} \mathrm{ppbv}^{-1}$, normally the result of STT processes in regions neighbouring the Canary Islands (North Africa, and the corridor extending from Great Britain to the Canaries).

To summarize, tropospheric $\mathrm{O}_{3}$ recorded in the subtropical North Atlantic is the result of the interaction between transport of photochemical produced $\mathrm{O}_{3}$ within the North American $\mathrm{CBL}$, the in situ photochemical $\mathrm{O}_{3}$ produced within the FT during its transport over the North Atlantic, and the "natural" $\mathrm{O}_{3}$ intrusions from the lower stratosphere over the North Atlantic and North Africa. However, we cannot discern the relative contribution of each main source quantitatively. For this, further studies are needed which might be supported with photochemical model simulations.

Finally, the role played by the NAO in the $\mathrm{O}_{3}$ content over the North Atlantic, and specifically at IZO has been analyzed. The predominant high positive phase of NAO changes appreciably from 1995-1996. Since this date the NAO alternates between negative or neutral phases and positive phases. This change in the pattern of atmospheric circulation over the North Atlantic results in an increased flow of the westerlies in the mid-latitude and subtropical North Atlantic, thus favouring the transport of $\mathrm{O}_{3}$ and its precursors from North America, and a higher frequency of storms over North Atlantic, with a likely higher incidence of STT exchange processes in mid latitudes. This resulted in an increase of tropospheric $\mathrm{O}_{3}$ in the subtropical North Atlantic region after 1996 that has been reflected in surface $\mathrm{O}_{3}$ records at IZO.

Averaged TOR data in winter for years with NAO $<-0.5$ shows higher tropospheric $\mathrm{O}_{3}$ amounts on most of our study region, and clearly in the eastern North Atlantic compared to years with $\mathrm{NAO}>+0.5$. In spring there is a significant increase in tropospheric $\mathrm{O}_{3}$ in a band that stretches across the eastern North Atlantic (over the Canaries), North Africa, the western Mediterranean basin, and southern countries of Eastern Europe in years with negative phase of NAO. These results are confirmed by surface $\mathrm{O}_{3}$ at IZO. Years with $\mathrm{NAO}<-0.5$ show surface $\mathrm{O}_{3}$ values systematically higher than those for years with NAO $>+0.5$. The highest differences between the two phases of NAO are observed in spring
( $\sim 3$ ppbv), and the lowest in autumn ( $\sim 1 \mathrm{ppbv})$. This is an important issue in $\mathrm{O}_{3}$ trend analysis since changes in the phase of the NAO could mask changes in emission of $\mathrm{O}_{3}$ precursors that have occurred in the last twenty years. $\mathrm{O}_{3}$ trends over the subtropical North Atlantic region must be properly interpreted taking into consideration phases of NAO. There is still considerable uncertainty in the prediction of NAO, but some studies suggest an intensification of the positive phase of NAO in a scenario of global warming (Gillett et al., 2003), which would impact on the content of tropospheric $\mathrm{O}_{3}$ over the North Atlantic through the atmospheric mechanisms analyzed in this work.

Acknowledgements. This study has been developed within the GAW Programme at the Izaña Atmospheric Research Center, financed by AEMET. We are particularly grateful to the Izaña Observatory staff (www.aemet.izana.org) for carrying out carefully essential routine operations. We appreciate the accurate audits performed by the World Calibration Centre (WCC-Empa) for Surface Ozone, Carbon Monoxide, Methane and Carbon Dioxide, for providing a trustful and creditable $\mathrm{O}_{3}$ and $\mathrm{CO}$ data quality assurance system at the Izaña Observatory. Data of radiotracers were obtained from the AEROCE project (Joseph Prospero as Principal Investigator). The authors would also like to express their gratitude to NOAA-ARL for the provision of the HYSPLIT transport and dispersion model (www.arl.noaa.gov/ready.html) used in this publication. PV data have been obtained from ERA-Interim ECMWF reanalysis. Monthly NAO index data have been obtained from NOAA/CPC. Zonal wind datasets were retrieved from NCEP/NCAR reanalysis. TOR data have been computed from the database available at the NASA site http://asd-www.larc.nasa.gov/TOR/data.html. We thank NOAA/ESRL, Federal Environment Agency Germany, EMPA, and Federal Environment Agency Austria for the surface ozone measurements carried out at Mauna Loa, Zugspitze-Schneefernerhaus, Jungfraujoch, and Sonnblick, respectively. Ozone data have been downloaded from the World Data Centre for Greenhouse Gases (WDCGG; http://ds.data.jma.go.jp/gmd/wdcgg/), which is also acknowledged.

Edited by: N. Mihalopoulos

\section{References}

Akritidis, D., Zanis, P., Pytharoulis, I., Mavrakis, A., and Karacostas, Th.: A deep stratospheric intrusion event down to the earth's surface of the megacity of Athens, Meteorol. Atmos. Phys., 109, 9-18, doi:10.1007/s00703-010-0096-6, 2010.

Alonso-Pérez, S., Cuevas, E., Querol, X., Viana, M., and Guerra, J.: Impact of the Saharan dust outbreaks on the ambient levels of total suspended particles (TSP) in the marine boundary layer (MBL) of the Subtropical Eastern North Atlantic Ocean, Atmos. Environ., 41, 9468-9480, 2007.

Alonso-Pérez, S., Cuevas, E., Pérez, C., Querol, X., Baldasano, J., Draxler, R., and de Bustos, J.: Trend changes of African airmass intrusions in the marine boundary layer over the subtropical 
Eastern North Atlantic region in winter, Tellus B, 63B, 255-265, 2011.

Andrade, C., Trigo, R., Freitas, M., Gallego, M., Borges, P., and Ramos, A.: Comparing historic records of storm frequency and the North Atlantic Oscillation (NAO) chronology for the Azores region, The Holocene, 18, 745-754, 2008.

Andrey, J., Gil, M., Alonso-Pérez, S., Parrondo, C., Redondas, A., and Cuevas, E.: Tropospheric ozone under Saharan dust: a statistical study on vertical distribution, in: International Aerosol Conference, number 873, Helsinki (Finland), 29 August-3 September, 2010.

Appenzeller, C., Davies, H., and Norton, W.: Fragmentation of stratospheric intrusions, J. Geophys. Res., 101, 1435-1456, 1996.

Appenzeller, C., Weiss, A., and Staehelin, J.: North Atlantic oscillation modulates total ozone winter trends, Geophys. Res. Lett., 27, 1131-1134, 2000.

Auvray, M. and Bey, I.: Long-range transport to Europe: seasonal variations and implications for the European ozone budget, Geophys. Res. Lett., 110, D11303, doi:10.1029/2004JD005503, 2005.

Balkanski, Y. J., Jacob, D., Gardner, G., Graustein, W., and Turekian, K.: Transport and residence times of tropospheric aerosols inferred from a global three-dimensional simulation of ${ }^{210} \mathrm{~Pb}$, J. Geophys. Res., 98, 20573-20586, 1993.

Beekman, M., Ancellet, G., and Megie, G.: Climatology of tropospheric ozone in southern Europe and its relation to potential vorticity, J. Geophys. Res., 99, 12841-12853, 1994.

Berkowtiz, C., Daum, P., Spicer, C., and Busness, K.: Synoptic patterns associated with the flux of excess ozone to the western North Atlantic, J. Geophys. Res., 101, 28923-28933, 1996.

Bonasoni, P., Evangelisti, F., Bonafe, U., Ravegnani, F., Calzolari, F., Stohl, A., Tositti, L., Tubertini, O., and Colombo, T.: Stratospheric ozone intrusion episodes recorded at Mt. Cimone during the VOTALP project: case studies, Atmos. Environ., 34, 1355-1365, 2000.

Bonasoni, P., Cristofanelli, P., Calzolari, F., Bonafè, U., Evangelisti, F., Stohl, A., Zauli Sajani, S., van Dingenen, R., Colombo, T., and Balkanski, Y.: Aerosol-ozone correlations during dust transport episodes, Atmos. Chem. Phys., 4, 1201-1215, doi:10.5194/acp4-1201-2004, 2004.

Chiapello, I., Moulin, C., and Prospero, J.: Understanding the longterm variability of African dust transport across the Atlantic as recorded in both Barbados surface concentrations and large-scale Total ozone Mapping Spectrometer (TOMS) optical thickness, J. Geophys. Res., 110, D18S10, doi:10.1029/2004JD005132, 2005.

Chin, M., Jacob, D., Munger, J., Parrish, D. D., and Doddridge, B.: Relationship of ozone and carbon monoxide over North America, J. Geophys. Res., 99, 14565-14573, doi:10.1029/2004JD005132, 1994.

Cooper, O. and Parrish, D.: Air Pollution Export from and Emport to North America: Experimental Evidence, The Handbook of Environmental Chemistry, vol. 4G, Springer, New York, 2004.

Cooper, O., Moody, J., Parrish, D., Trainer, M., Holloway, J., Ryerson, T., Hüler, G., Fehsenfeld, F., Oltmans, S., Evans, M., and Evans, M. J.: Air Pollution Export from and Emport to North America: Experimental Evidence, vol. 4G, Springer, New York, 2002.
Creilson, J. K., Fishman, J., and Wozniak, A. E.: Intercontinental transport of tropospheric ozone: a study of its seasonal variability across the North Atlantic utilizing tropospheric ozone residuals and its relationship to the North Atlantic Oscillation, Atmos. Chem. Phys., 3, 2053-2066, doi:10.5194/acp-3-2053-2003, 2003.

Cristofanelli, P., Bonasoni, P., Tositti, L., Bonafè, U, Calzolari, F. Evangelisti, F., Sandrini, S., and Stohl, A.: A 6-year analysis of stratospheric intrusions and their influence on ozone at Mt. Cimone (2165 m above sea level), J. Geophys. Res., 111, D03306, doi:10.1029/2005JD006553, 2006.

Cuevas, E.: Estudio del Comportamiento del Ozono Troposférico en el Observatorio de Izaña (Tenerife) y su Relación con la Dinámica Atmosférica, Ph. D. thesis, Facultad de Ciencias Físicas, Universidad Complutense de Madrid, 1995.

Cuevas, E. and Rodríguez, J.: Statistics of cutoff lows over the North Atlantic (in Spanish), in: Proceedings Tercera Asamblea Hispano-Portuguesa de Geodesia y Geofisica, Valencia, Spain, 4-8 February, 2002, 1-3, Comision Española de Geodesia y Geofisica, Edited by Editorial UPV, Valencia, Spain, 2002.

Cuevas, E., Díaz, A., and Martín, F.: Atmospheric Carbon Dioxide Concentration at Izaña BAPMoN Observatory, Canary Islands, 1984-1990, in: Proceedings 19th ITM on Air Pollution Modeling and its Applications, NATO/CCMS, Ierapetra, Greece, 29 September-4 October 1991, 45-46, edited by: van Dop, H. and Kallos, G., Plenum Press, New York, USA, 1992.

Cuevas, E., Diamantino, V., and Sancho, J.: StratosphereTroposphere Exchange events over North Atlantic subtropical region, in: Proc. Second Asamblea Hispano Portuguesa de Geodesia y Geofisica, edited by Instituto Geofisico do Infante D. Luis (Portugal), S11-16, 451-452, Lagos (Portugal), 8-12 February, 2000.

Danielsen, E.: Stratospheric-tropospheric exchange based on radioactivity ozone and potential vorticity, J. Atmos. Sci., 25, 502 $518,1968$.

de Reus, M., Dentener, F., Thomas, A., Borrmann, S. J. S., and Lelieveld, J.: Airborne observations of dust aerosol over the North Atlantic Ocean during ACE 2 - indications for heterogeneous ozone destruction, J. Geophys. Res., 105, 15263-15275, doi:10.1029/2000JD900164, 2000.

Dickerson, R., Doddridge, B., Kelley, P., and Rhoads, K.: Large scale pollution of the atmosphere over the remote Atlantic Ocean: evidence from Bermuda, J. Geophys. Res., 10, 89458952, 1995.

Draxler, R. and Rolph, G.: HYSPLIT (Hybrid Single-Particle Lagrangian Integrated Trajectory) Model access via NOAA ARL READY, Tech. rep., NOAA Air Resources Laboratory, Silver Spring, MD, available at: http://www.arl.noaa.gov/ready/ hysplit4.html (last access: March 2012), 2003.

Duncan, B. N. and Bey, I.: A modeling study of the export pathways of pollution from Europe: seasonal and interannual variations (1987-1997), J. Geophys. Res., 109, D08301, doi:10.1029/2003JD004079, 2004.

Eckhardt, S., Stohl, A., Beirle, S., Spichtinger, N., James, P., Forster, C., Junker, C., Wagner, T., Platt, U., and Jennings, S. G.: The North Atlantic Oscillation controls air pollution transport to the Arctic, Atmos. Chem. Phys., 3, 1769-1778, doi:10.5194/acp-31769-2003, 2003. 
Evan, A. T., Heidinger, A. K., and Knippertz, P.: Analysis of winter dust activity off the coast of West Africa using a new 24-year over-water advanced very high resolution radiometer satellite dust climatology, J. Geophys. Res., 111, D12210, doi:10.1029/2005JD006336, 2006.

Fishman, J. and Balok, A. E.: Calculation of daily tropospheric ozone residuals using TOMS and empirically improved SBUV measurements: application to an ozone pollution episode over the Eastern United States, J. Geophys. Res., 104, 30319-30340, 1999.

Fishman, J. and Crutzen, P.: The Origin of ozone in the troposphere, Nature, 274, 855-858, 1978.

Fishman, J., Wozniak, A. E., and Creilson, J. K.: Global distribution of tropospheric ozone from satellite measurements using the empirically corrected tropospheric ozone residual technique: Identification of the regional aspects of air pollution, Atmos. Chem. Phys., 3, 893-907, doi:10.5194/acp-3-893-2003, 2003.

Fleming, Z., Monks, P., and Manning A.: Untangling the influence of air-mass history in interpreting observed atmospheric composition, Atmos. Res., 104-105, 1-39, 2012.

Font, I.: El Tiempo Atmosférico de las Islas Canarias, Servicio Meteorológico Nacional, Serie A, no. 26, INM, Madrid, 1956.

Gerasopoulos, E., Zanis, P., Stohl, A., Zerefos, C., Papastefanou, C., Ringer, W., Tobler, L., Hübener, S., Gäggeler, H., Kanter, H., Tositti, L., and Sandrini, S.:A climatology of 7Be at four highaltitude stations at the Alps and the Northern Apennines, Atmos. Environ., 35, 6347-6360, 2001.

Gilge, S., Plass-Duelmer, C., Fricke, W., Kaiser, A., Ries, L., Buchmann, B., and Steinbacher, M.: Ozone, carbon monoxide and nitrogen oxides time series at four alpine GAW mountain stations in central Europe, Atmos. Chem. Phys., 10, 12295-12316, doi:10.5194/acp-10-12295-2010, 2010.

Gillett, N., Graf, H., and Osborn, T. J.: The North Atlantic Oscillation: climatic significance and environmental impact, in: Geophys. Monogr. Ser., edited by: Hurrell, J., Kushnir, Y, Ottersen, G. and Visbeck, M., vol. 134, AGU, Washington, DC, 193-210, 2003.

Gómez-Peláez, A., Ramos, R., and Pérez-delaPuerta, J.: Methane and Carbon Dioxide Continuous Measurements at Izaña GAW station (Spain), in: 13th WMO/IAEA Meeting Experts on Carbon Dioxide, other Greenhouse gases, and Related Tracer Measurements Techniques, edited by: Miller, J., World Meteorological Organization (TD No. 1359), Boulder, Colorado, USA, 19-22 September, 2005, World Meteorological Organization, available at: ftp://ftp.wmo.int/Documents/PublicWeb/arep/gaw/ gaw168.pdf (last access: February 2013), 180-184, 2006.

Gómez-Peláez, A. J., Ramos, R., Cuevas, E., and Gómez-Trueba, $\mathrm{V} .: 25$ years of continuous $\mathrm{CO}_{2}$ and $\mathrm{CH}_{4}$ measurements at Izaña Global GAW mountain station: annual cycles and interannual trends; Proceedings of the "Symposium on Atmospheric Chemistry and Physics at Mountain Sites (ACP Symposium 2010, 8-10 June 2010, Interlaken, Switzerland)", available at: http:// www.maiolica.ch/publications/ACP-Symposium-Abstracts.pdf (last access: February 2013), 157-159, 2010.

Gómez-Peláez, A. J., Ramos, R., Gomez-Trueba, V., Novelli, P. C., and Campo-Hernandez, R.: A statistical approach to quantify uncertainty in carbon monoxide measurements at the Izaña global GAW station: 2008-2011, Atmos. Meas. Tech. Discuss., 5, 6949-6989, doi:10.5194/amtd-5-6949-2012, 2012.
Graustein, W. and Turekian, K.: ${ }^{7} \mathrm{Be}$ and ${ }^{210} \mathrm{~Pb}$ indicate an upper troposphere source for elevated ozone in the summertime subtropical free troposphere of the Eastern North Atlantic, Geophys. Res. Lett., 23, 539-542, 1996.

Güsten, H., Heinrich, G., Mönnich, E., Sprung, D., Weppner, J., Ramadan, A. B., Ezz El-Din, M. R. M., Ahmed, D. M., and Hassan, G. K. Y.: On-line measurements of ozone surface fluxes, II, surface level ozone fluxes onto the Sahara desert, Atmos. Environ., 30, 911-918, 1996.

Hegarty, J., Mao, H., and Talbot, R.: Synoptic influences on springtime tropospheric $\mathrm{O}_{3}$ and $\mathrm{CO}$ over the North American export region observed by TES, Atmos. Chem. Phys., 9, 3755-3776, doi:10.5194/acp-9-3755-2009, 2009.

Honrath, R. E., Owen, R. C., and Val Martin, M. E. A.: Regional and hemispheric impacts of anthropogenic and biomass burning emissions on summertime $\mathrm{CO}$ and ozone in the North Atlantic lower free troposphere, J. Geophys. Res., 109, D24310, doi:10.1029/2004JD005147, 2004.

Hopke, P., Zhou, L., and Poirot, R.: Reconciling trajectory ensemble receptor model results with emissions, Environ. Sci. Technol., 39, 7980-7983, 2005.

Hoskins, B. J., McIntyre, M., and Robertosn, A.: On the use and significance of isentropic potential vorticity maps, Q. J. Roy. Meteorol. Soc., 111, 877-946, 1985.

Hurrell, J. W. and Dickson, R. R.: Climate variability over the North Atlantic. Marine Ecosystems and Climate Variation: The North Atlantic, edited by: Stenseth, N. C., Ottersen, G., Hurrell, J. W., and Belgrano, A., Oxford University Press, 15-31, 2004.

Hurrell, J., Kushnir, Y., Ottersen, G., and Visbeck, M.: The North Atlantic Oscillation: Climate Significance and Environmental Impact, Geophysical Monograph Series, 134, American Geophysical Union, Washington DC, USA, 2003.

James, P., Stohl, A., Foster, C., Eckhard, S., Seibert, P., and Frank, A.: A 15-years climatology of stratosphere-troposphere exchange with a Lagrangian particle dispersion model: 2. Mean climate and seasonal variability, J. Geophys. Res., 108, 8522, doi:10.1029/2002JD002636, 2003.

Jonson, J. E., Simpson, D., Fagerli, H., and Solberg, S.: Can we explain the trends in European ozone levels?, Atmos. Chem. Phys., 6, 51-66, doi:10.5194/acp-6-51-2006, 2006.

Junge, C.: Global ozone budget and exchange between stratosphere and troposphere, Tellus, 14, 363-377, 1962.

Kasibhatla, P., Levy II, H., Klonecki, A., and Chameides, W. L.: Three-dimensional view of the large-scale tropospheric ozone distribution over the North Atlantic Ocean during summer, J. Geophys. Res., 101, 29305-29316, 1996.

Kentarchos, A., Roelofs, G., Lelievel, J., and Cuevas, E.: On the origin of elevated surface ozone concentrations at Izaña Observatory, Tenerife during late March 1996, Geophys. Res. Lett., 27, 3699-3702, 2000.

Lelieveld, J. and Dentener, F.: What controls tropospheric ozone?, J. Geophys. Res., 105, 3531-3551, 2000.

Levy, H. I.: Normal atmosphere: large radical and formaldehyde concentrations predicted, Science, 173, 141-143, 1971.

Levy, H. I., Mahlman, J., Moxim, W., and Liu, S.: Tropospheric ozone: the role of transport, J. Geophys. Res., 90, 3753-3772, 1985.

Li, Q., Jacob, D., Bey, I., Palmer, P., Duncan, B. N., Field, B. D., Martin, R. V., Fiore, A. M., Yantosca, R. M., Parrish, D. D., Sim- 
monds, P. G., and Oltmans, S.: Transatlantic transport of pollution and its effects on surface ozone in Europe and North America, J. Geophys. Res., 107, 4166, doi:10.1029/2001JD001422, 2002a.

Li, Q., Jacob, D., Fairlie, T., Liu, H., Yantosca, R., and Martin, R.: Stratospheric versus pollution influences on ozone at Bermuda: reconciling past analyses, J. Geophys. Res., 107, 4611, doi:10.1029/2002JD002138, 2002b.

Logan, J.: Tropospheric ozone: seasonal behavior, trends, and antropogenic influence, J. Geophys. Res., 90, 10463-10482, 1985.

Logan, J., Staehelin, J., Megretskaia, I., Cammas, J., Thouret, V., Claude, H., De Backer, H., Steinbacher, M., Scheel, H., Stübi, R., Fröhlich, M., Derwent, R.: Changes in ozone over Europe: Analysis of ozone measurements from sondes, regular aircraft (MOZAIC) and alpine surface sites, J. Geophys. Res., 117, D09301, doi:10.1029/2011JD016952, 2012.

London, J. and Liu, S.: Long-term tropospheric and lower stratospheric ozone variations from ozonesonde observations, J. Atmos. Terr. Phys., 54, 599-625, 1992.

Mao, H., Talbot, R., Troop, D., Johnson, R., Businger, S., and Thompson, A. M.: Smart balloon observations over the North Atlantic: ozone data analysis and modeling, J. Geophys. Res., 111, 599-625, doi:10.1029/2005JD006507, 2006.

Millán, M., Salvador, R., Mantilla, E., and Kallos, G.: Photooxidant dynamics in the Mediterranean Basin in summer: results from European research projects, J. Geophys. Res., 102, 88118823, 1997.

Mitchel, J.: The greenhouse effect and climate change, Rev. Geophys., 27, 115-139, 1989.

Moody, J. L., Davenport, J. C., Merrill, J. T., Oltmans, S. J., Parrish, D. D., Holloway, J. S., Levy II, H., Forbes, G. L., Trainer, M., and Buhr, M.: Meteorological mechanisms for transporting ozone over the western North Atlantic Ocean: a case study for August 24-29, J. Geophys. Res., 101, 29213-29227, 1996.

Nienerowski, K.: Qualitatssicherungs-Handbuch des UBAMessnetzes, UBA Texte 28/04, Handbook for quality assurance for the measurement network for the Federal Environmental Agency, Umweltbundesamt, Berlin, Germany, June, 2004.

Nieto, R., Gimeno, L., Ribera, P., Gallego, D., García, R., and Hernández, E.: Effects of the North Atlantic Oscillation on the spatial distribution of cut-off low (COL) systems in the Northern Hemisphere, in: Proceedings of the AGU Chapman Conference "The North Atlantic Oscillation", Vigo, Spain, 28 November-1 December, available at: http://xtide.ldeo.columbia.edu/ visbeck/ nao/poster/ (last access: October, 2012), 2000.

Nieto, R., Gimeno, L., de la Torre, L., Ribera, P., Gallego, D., García-Herrera, R., García, J., Núñez, M., Redaño, A., and Lorente, J.: Climatological features of cut-off low systems in the Northern Hemisphere, J. Climate, 18, 3085-3103, 2005.

Oltmans, S. and Levy II, H.: Seasonal cycle of surface ozone over the Western North Atlantic, Nature, 358, 392-394, 1992.

Oltmans, S. and Levy II, H.: Surface ozone measurements from a global network, Atmos. Environ., 28, 9-24, 1994.

Oltmans, S., Levy II, H., Harris, J., Merrill, J., Moody, J., Lathrop, J., Cuevas, E., Trainer, M., O’Neill, M., Prospero, J., Vömel, H., and Johnson, B.: Summer and spring ozone profiles over the North Atlantic from ozonesonde measurements, J. Geophys. Res., 101, 29179-29200, 1996.
Oltmans, S., Lefohn, A., Harris, J., Galbally, I., Scheel, H., Bodeker, G., Brunke, E., Claude, H., Tarasick, D., Johnson, B., Simmonds, P., Shadwick, D., Anlauf, K., Hayden, K., Schmidlin, F., Fujimoto, T., Akagi, K., Meyer, C., Nichol, S., Davies, J., Redondas, A., and Cuevas, E.: Long-term changes in tropospheric ozone, Atmos. Environ., 40, 3156-3173, 2006.

Oltmans, S., Lefohn, A., Shadwick, D., Harris, J., Scheel, H. Galbally, I., Tarasick, D., Johnson, B., Brunke, E., Claude, H., Zeng, G., Nichol, S., Schmidlin, F., Davies, J., Cuevas, E., Redondas, A., Naoe, H., Nakano, T., and Kawasato, T.: Recent tropospheric ozone changes - A pattern dominated by slow or no growth, Atmos. Environ., 67, 331-351, 2013.

Ordóñez, C., Brunner, D., Staehelin, J., Hadjinicolaou, P., Pyle, J., Jonas, M., Wernli, H., and Prevot, A. S. H.: Strong influence of lowermost stratospheric ozone on lower tropospheric background ozone changes over Europe, Geophys. Res. Lett., 34, L07805, doi:10.1029/2006GL029113, 2007.

Owen, R. C., Cooper, O. R., Stohl, A., and Honrath, R. E.: An analysis of the mechanisms of North American pollutant transport to the Central North Atlantic lower free troposphere, J. Geophys. Res., 111, D23S58, doi:10.1029/2006JD007062, 2006.

Parrish, D., Holloway, J. S., Trainer, M., Murphy, P., Forbes, G., and Fehsenfeld, F.: Export of North American ozone pollution to the North Atlantic Ocean, Science, 259, 1436-1439, doi:10.1126/science.259.5100.1436, 1993.

Parrish, D. D., Holloway, J. S., and Jakoubek, R. E. A.: Mixing of anthropogenic pollution with stratospheric ozone: a case study from the North Atlantic wintertime troposphere, J. Geophys. Res., 105, 24363-24374, 2000.

Pausata, F. S. R., Pozzoli, L., Vignati, E., and Dentener, F. J.: North Atlantic Oscillation and tropospheric ozone variability in Europe: model analysis and measurements intercomparison, Atmos. Chem. Phys., 12, 6357-6376, doi:10.5194/acp-12-63572012, 2012.

Poirot, R. and Wishinski, P.: Visibility, sulphate and air mass history associated with the summertime aerosol in Northern Vermont, Atmos. Environ., 20, 1457-1469, 1986.

Prather, M., Gauss, M., and Berntsen, T. E. A.: Fresh air in the 21st century?, Geophys. Res. Lett., 30, 1100, doi:10.1029/2002GL016285, 2003.

Prospero, J. and Carlson, T.: Saharan air outbreaks over the tropical North Atlantic, Pageoph., 119, 677-691, doi:10.1029/2002GL016285, 1981.

Prospero, J., Schmitt, R., Cuevas, E., Savoie, D., Graustein, W., Turekian, K., Volz-Thomas, A., Díaz, A., Oltmans, S., and Levy, H.: Temporal variability of ozone and aerosols in the free troposphere over the Eastern North Atlantic, Geophys. Res. Letts., 22, 2925-2928, 1995.

Raes, F., VanDingenen, R., Cuevas, E., VanVelthoven, P. F. J., and Prospero, J. M.: Observations of aerosols in the free troposphere and marine boundary layer of the subtropical Northeast Atlantic: discussion of processes determining their size distribution, J. Geophys. Res., 102, 21315-21328, 1997.

Ramanathan, V., Cicerone, R., Singh, H. B., and Kiehl, J.: Trace gas trends and their potential role in climate change, J. Geophys. Res., 90, 5547-566, 1985.

Rao, T. N., Kirkwood, S., Arvelius, J., von der Gathen, P., and Kivi, R.: Climatology of UTLS ozone and the ratio of ozone and potential vorticity over northern Europe, J. Geophys. Res., 108, 
4703, doi:10.1029/2003JD003860, 2003.

Reiter, R., Munzert, K., Kanter, H., and Poetzl, K.: Cosmogenic radionuclides and ozone at a mountain station at $3.0 \mathrm{~km}$ a.s.1., Tech. Rep., Arc. Met. Geoph.Biocl., Ser. B, 32, 131-160, GarmischPartenkirchen, Germany, doi:10.1007/BF02273971, 1983.

Rodríguez, S., Torres, C., Guerra, J., and Cuevas, E.: Transport pathways of ozone to marine and free-troposphere sites in Tenerife, Canary Islands, Atmos. Environ., 38, 4733-4747, 2004.

Rodríguez, S., Alastuey, A., Alonso-Pérez, S., Querol, X., Cuevas, E., Abreu-Afonso, J., Viana, M., Pérez, N., Pandolfi, M., and de la Rosa, J.: Transport of desert dust mixed with North African industrial pollutants in the subtropical Saharan Air Layer, Atmos. Chem. Phys., 11, 6663-6685, doi:10.5194/acp-11-66632011, 2011.

Rolph, G.: Real-time Environmental Applications and Display System (READY), Tech. rep., NOAA Air Resources Laboratory, Silver Spring, M. D., available at: http://www.arl.noaa.gov/ready/ hysplit4.html (last access: September 2012), 1983.

Scheel, H.-E.: Ozone climatology studies for the Zugspitze and neighboring sites in the German Alps, edited by: Lindskog, A., TOR-2 Final Report, EUROTRAC-2 ISS, 134-139, GSF Research Center, Munich, Germany, 1983.

Schmitt, R. and Carretero, P.: Ozone in the Free Troposphere Over The North Atlantic: Production and Long-Range Transport, edited by Hov,Ø., EUROTRAC-2, German Research Center for Environmental Health (GmbH), Munich, Germany, 1992.

Schuepbach, E., Friedli, T., Zanis, P, Monks, P., and Penkett, S.: State space analysis of trends and seasonalities of lower free tropospheric ozone (1988-1997) at the high elevation site at Jungfraujoch, J. Geophys. Res., 106, 20413-20427, 2001.

Shapiro, M., Hampel, T., and Krueger, A.: The arctic tropopause fold, Mon. Weather Rev., 115, 444-454, 1987.

Solomon, S., Qin, D., Manning, M., Chen, Z., Marquis, M., Averyt, K., Tignor, M., and Miller, H. (Eds.): IPCC AR4 WG1, Climate Change 2007: The Physical Science Basis, Contribution of Working Group I to the Fourth Assessment Report of the Intergovernmental Panel on Climate Change, Cambridge University Press, Cambridge, UK and New York, NY, USA, 2007.

Sprenger, M. and Wernli, H.: A northern hemispheric climatology of cross-tropopause exchange for the ERA15 time period (19791993), J. Geophys. Res., 108, 8521, doi:10.1029/2002JD002636, 2003.

Staehelin, J. and Poberaj, C.: Long-term Tropospheric ozone Trends: a Critical Review, vol. 33, Advances in Global Change Research, Climate Variability and Extremes during the Past 100 Years, IV, edited by: Bronniman, S., Luterbacher, J., Ewen, T., Diaz, H, Stolarski, R., Neu, U., Springer, Geneva, Switzerland, 2008.

Stohl, A.: A 1-year Lagrangian "climatology" of airstreams in the Northern Hemisphere troposphere and lowermost stratosphere, J. Geophys. Res., 106, 7263-7279, 2001.

Stohl, A. and Trickl, T.: A textbook example of long-range transport: simultaneous observation of ozone maxima of stratospheric and North American origin in the free troposphere over Europe, J. Geophys. Res., 104, 30445-30462, 1999.

Stohl, A., Spichtinger-Rakowsky, N., Bonasoni, P., Feldmann, H., Memmesheimer, M., Scheel, H., Trickl, T., Hübener, S., Ringer, W., and Mandl, M.: The influence of stratospheric intrusions on alpine ozone concentrations, Atmos. Environ., 34,
1323-1354, 2000

Stohl, A., Eckhardt, S., Forster, C., James, P., and Spichtinger, N.: On the pathways and timescales of intercontinental air pollution transport, J. Geophys. Res., 107, 4684 doi:10.1029/2001JD001396, 2002.

Tarasova, O., Elansky, N., Kuznetsov, G., Kuznetsova, I., and Senik, I.: Impact of air transport on seasonal variations and trends of surface ozone at Kislovodsk High Mountain stations, J. Atmos. Chem., 45, 245-259, doi:10.1029/2002JD002636, 2003.

Tarasova, O. A., Senik, I. A., Sosonkin, M. G., Cui, J., Staehelin, J., and Prévôt, A. S. H.: Surface ozone at the Caucasian site Kislovodsk High Mountain Station and the Swiss Alpine site Jungfraujoch: data analysis and trends (1990-2006), Atmos. Chem. Phys., 9, 4157-4175, doi:10.5194/acp-9-4157-2009, 2009.

Thompson, A.: The oxidizing capacity of the Earth's atmosphere: probable past and future changes, Science, 256, 1157-1165, 1992.

Tiao, G., Box, G., and Hamming, W.: Analysis of Los Angeles photochemical smog data: a statistical overview, J. Air Poll. Control Assoc., 25, 260-268, 1975.

Tripathi, O. P., Jennings, S. G., O’Dowd, C. D., Coleman, L., Leinert, S., O'Leary, B., Moran, E., O'Doherty, S., and Spain, T. G.: Statistical analysis of eight surface ozone measurement series for various sites in Ireland, J. Geophys. Res., 115, 85-89, doi:10.1029/2010JD014040, 2010.

Turekian, K. K., Nozaki, Y., and Benninger, L. K.: Geochemistry of atmospheric radon and radon products, Annu. Rev. Earth Planet. Sci., 5, 227-255, 1977.

Val Martin, M., Honrath, R. E., Owen, R. C., and Lapina, K.: Largescale impacts of anthropogenic pollution and boreal wildfires on the nitrogen oxides over the central North Atlantic region, J. Geophys. Res., 113, D17308, doi:10.1029/2007JD009689, 2008.

Viezee, W. and Singh, H. B.: The distribution of beryllium-7 in the troposphere, implications on stratosphere/tropospheric air exchange, Geophys. Res. Lett., 7, 805-808, 1980.

Vingarzan, R.: A review of surface ozone background levels and trends, Atmos. Environ., 38, 3431-3442, 2004.

Wallace, J. and Gutzler, D. S.: Teleconnections in the geopotential height field during the Northern Hemisphere winter, Mon. Weather Rev., 109, 784-812, 1981.

Wernli, H. and Bourqui, M.: A Lagrangian "1-year climatology" of (deep) cross-tropopause exchange in the extratropical Northern Hemisphere, J. Geophys. Res., 107, 4021, doi:10.1029/2001JD000812, 2002.

WMO: Meteorology a Three-Dimensional Science: Second Session of the Commission for Aerology, WMO Bulletin IV(4), Tech. rep., NOAA Air Resources Laboratory, Geneva, 1957.

Yienger, J. J., Klonecki, A. A., Levy II, H., Moxim, W. J., and Carmichael, G. R.: An evaluation of chemistry's role in the winter-spring ozone maximum found in the northern midlatitude free troposphere, J. Geophys. Res., 104, 3655-3667, doi:10.1029/1998JD100043, 1999.

Zanis, P., Schuepbach, E., Gäggeler, H.W., Hübener, S., and Tobler, L.: Factors controlling beryllium-7 at Jungfraujoch in Switzerland, Tellus B, Vol. 51, 4, 789-805, 1999. 